\title{
The role of reproductive hormones in epithelial ovarian carcinogenesis
}

\author{
Helen Gharwan', Kristen P Bunch ${ }^{2,3}$ and Christina M Annunziata ${ }^{2}$ \\ ${ }^{1}$ National Cancer Institute, National Institutes of Health, 10 Center Drive, Building 10, 12N226, Bethesda, \\ Maryland 20892-1906, USA \\ ${ }^{2}$ Women's Malignancies Branch, National Cancer Institute, National Institutes of Health, Center for Cancer Research, \\ Bethesda, Maryland, USA \\ ${ }^{3}$ Department of Gynecologic Oncology, Walter Reed National Military Medical Center, Bethesda, Maryland, USA
}

Correspondence

should be addressed

to H Gharwan

Email

hgh7@hotmail.com

\begin{abstract}
Epithelial ovarian cancer comprises $\sim 85 \%$ of all ovarian cancer cases. Despite acceptance regarding the influence of reproductive hormones on ovarian cancer risk and considerable advances in the understanding of epithelial ovarian carcinogenesis on a molecular level, complete understanding of the biologic processes underlying malignant transformation of ovarian surface epithelium is lacking. Various hypotheses have been proposed over the past several decades to explain the etiology of the disease. The role of reproductive hormones in epithelial ovarian carcinogenesis remains a key topic of research. Primary questions in the field of ovarian cancer biology center on its developmental cell of origin, the positive and negative effects of each class of hormones on ovarian cancer initiation and progression, and the role of the immune system in the ovarian cancer microenvironment. The development of the female reproductive tract is dictated by the hormonal milieu during embryogenesis. Intensive research efforts have revealed that ovarian cancer is a heterogenous disease that may develop from multiple extra-ovarian tissues, including both Müllerian (fallopian tubes, endometrium) and non-Müllerian structures (gastrointestinal tissue), contributing to its heterogeneity and distinct histologic subtypes. The mechanism underlying ovarian localization, however, remains unclear. Here, we discuss the role of reproductive hormones in influencing the immune system and tipping the balance against or in favor of developing ovarian cancer. We comment on animal models that are critical for experimentally validating existing hypotheses in key areas of endocrine research and useful for preclinical drug development. Finally, we address emerging therapeutic trends directed against ovarian cancer.
\end{abstract}

\section{Introduction}

Ovarian cancer is the fifth leading cause of cancer-related deaths among women and the gynecologic malignancy with the highest mortality rate in the USA (http://seer. cancer.gov/statfacts/html/ovary.html; accessed May 2015). Diagnosis is often delayed due to nonspecific symptomatology and a lack of early screening and detection methods (Goff et al. 2007, Andersen et al.
2010). Despite considerable research, the etiology of ovarian cancer remains elusive. A positive family history is a major risk factor for developing the disease (Walker et al. 2002), particularly in women with breast cancerassociated genes (BRCA) 1 and 2 mutations or genetic mutations associated with hereditary nonpolyposis colorectal cancer syndrome (Lu \& Broaddus 2005). Additional

Published by Bioscientifica Ltd. 
risk factors include increasing age with a predominance of disease occurrence/diagnosis in the fifth and sixth decades of life, early menarche (Gong et al. 2013), menopause after the age of 52 years (Tung et al. 2003), nulliparity (Tung et al. 2003), polycystic ovarian syndrome (PCOS, Schildkraut et al. 1996, Chittenden et al. 2009), primary infertility, endometriosis (Brinton et al. 2004), and lifestyle factors, such as tobacco use (Faber et al. 2013) and obesity (Calle et al. 2003, Olsen et al. 2007, Leitzmann et al. 2009). Each of these factors is coincident with fluctuations in reproductive hormones.

In recent years, the field of ovarian cancer research has more closely questioned and examined the true site of origin of the cancerous cells. It has been proposed that certain subtypes of tumors may arise from the distal fallopian tubes (FTs) rather than from the ovarian surface epithelium (OSE) and that stemlike cells within the cancerous tissue are responsible for tumor recurrence after successful initial remission (Cannistra 2004, Cooke $\&$ Brenton 2011). These advances have changed our understanding of the disease. Here, we provide an overview of the endocrine influences on tumor development and microenvironment of ovarian cancer, a tissue with more cellular heterogeneity than previously recognized. We discuss several relevant ovarian cancer animal models and summarize the current treatment options and future therapeutic trends.

\section{Developmental origins}

Until week 8 of human embryonic development, the internal reproductive tract is indifferent and undifferentiated in both genders. It consists of a set of two unipotential ducts - the Wolffian ducts (WDs) and the Müllerian ducts (MDs), also known as mesonephric and paramesophric ducts respectively. The MDs derive from cells of the coelomic epithelium (mesodermal in origin) that invaginate caudally toward the WDs and progress toward the urogenital sinuses. As the WDs regress, part of the coelomic epithelial cells proliferate and form the gonadal ridges (Byskov 1986). Early in embryonic development, the gonadal ridges and the mesonephros (urinary excretory organ of the early-stage embryo) are closely connected, but as the embryo grows, the structures separate. In females, the mesonephros degenerates and only a few mesonephric cells remain connected with the gonadal ridge. This cell mass is covered on its surface by the germinal epithelium and eventually develops into follicle-containing ovaries (Byskov 1986).
The etiology of epithelial ovarian cancer (EOC) is complex and not yet fully elucidated. Several hypotheses, all based on valid observations, have been discussed over the years, such as incessant ovulation (Fathalla 1971, Casagrande et al. 1979), cyclic or chronic inflammation (Ness \& Cottreau 1999, Ness \& Modugno 2006, Somigliana et al. 2006), stromal changes (Cramer \& Welch 1983), influence of androgen/progesterone (Risch 1998) or gonadotropins (Biskind \& Biskind 1944, Cramer \& Welch 1983), and follicle depletion (Smith \& Xu 2008). No single hypothesis, however, provides an all-inclusive explanation for the underlying pathogenesis of EOC.

\section{Ovarian cancer tissues of origin: lessons from embryologic development}

EOCs are traditionally classified into histologic subtypes based on morphological and functional features, and the tissues they mimic: serous (FT epithelium), endometrioid (proliferative endometrium), clear cell (endometriosis), mucinous (gastrointestinal tract or endocervical epithelium), and transitional cell/Brenner (urinary tract epithelium) (Chen et al. 2003). Ovarian/reproductive tract embryonic development and the close relationship of the structures in the early-stage embryo may be a reason for the propensity of OSE to differentiate into various types of epithelia during malignant transformation (Naora 2005). Likewise, de-differentiation of ovarian epithelia into one of the earlier developmental or embryonic tissues may explain the various ovarian cancer histologies. In accordance with our current understanding that ovarian cancer subtypes likely arise from other cell types within the female reproductive tract (FRT) than within the OSE, what has been historically termed 'ovarian cancer' could potentially be redefined in an embryologic descriptive manner as 'adenocarcinomas of Müllerian origin', although this designation may still not be entirely accurate and thus not acceptable to all (Dubeau 2008).

Serous cancers The epithelial cells covering the ovaries have historically been considered the site of origin of all ovarian cancers but recent evidence suggests that high-grade serous carcinoma (HGSC) originates from FT epithelium or the tuboperitoneal junction rather than the OSE (Piek et al. 2003, Crum et al. 2007, Kindelberger et al. 2007, Seidman et al. 2011, Tone et al. 2012). HGSCs are thought to originate in serous tubal intraepithelial carcinoma (STIC) lesions in the FTs, where ovulationrelated oxidative injury can result in genetic alterations and malignant transformation of the secretory epithelium

Published by Bioscientifica Ltd 
of the FT fimbriae. This theory is supported by the presence of occult neoplastic/STIC lesions found in up to $10 \%$ of FTs from BRCA mutation carriers who had undergone prophylactic bilateral salpingo-oophorectomies (Leeper et al. 2002, Crum et al. 2007). In a case series of prospectively identified EOC, evaluation of FT mucosa and ovarian tumors demonstrated similar genetic abnormalities and a monoclonal origin, implying a single primary site with secondary spread to other organs (Salvador et al. 2008). Based on this evidence implicating the FT as the origin of high-grade serous EOC, some groups have proposed performing salpingectomies as risk reduction surgery rather than oophorectomies in certain patients (Dietl et al. 2011).

The presence of a STIC lesion may potentiate the establishment of a 'p53 signature' (Lee et al. 2007), a putative p53 immunostain positive precursor lesion in the transition from nonmalignant distal FTs epithelium to carcinomatous epithelium, irrespective of whether a woman is a BRCA mutation carrier or not. However, whether or not the p53 signature truly represents a malignant precursor lesion has not been entirely elucidated yet, as equivalent lesions were also found in a high percentage of FTs of women without detectable STIC lesions or carcinomas (Lee et al. 2007). The observation that, when concurrently present in a woman, STIC lesions and ovarian carcinoma are associated in the majority, albeit not all, of the examined cases with identical TP53 mutations led to the hypothesis that the presence of a p53 signature in STIC lesions may reflect a precursor lesion for high-grade serous ovarian carcinoma was. This finding represented the basis for the postulation that clonal expansion and proliferation of cells with mutated TP53, loss of their polarity, and eventual shedding from the FTs may ultimately result in adhesion of these cells to the ovarian and/or peritoneal surface, thus giving the impression that the cancer originated from the epithelium of those surfaces (Lee et al. 2007, Jarboe et al. 2008). A recently published Swedish population-based cohort study of over 5 million women supports this hypothesis, as removal of the FTs by itself, or concomitantly with other benign surgery, was found to be an effective measure to reduce ovarian cancer risk in the general population (Falconer et al. 2015). This has been primarily attributed to the removal of STIC lesions with surgery.

In other, rarer cases, HGSCs lack TP53 mutations but are found to have KRAS mutations, suggesting that they may arise from low-grade serous carcinomas (Dehari et al. 2007), which typically develop in a stepwise fashion, starting as benign serous lesions and progressing to atypical or serous borderline tumors on acquisition of a $K R A S$ or $B R A F$ mutation and eventually developing into invasive cancers.

Endometrioid and clear cell cancers The FTs present an open conduit between the lower genital tract and the peritoneal cavity that enables the transport of potential carcinogens (Cramer et al. 1982, Huncharek et al. 2003), pathogens, inflammatory mediators, and malignant cells from other locations of the reproductive tract to the ovaries. For example, retrograde menstruation may transfer endometrial or cervical cells to the ovaries (Sampson 1927, D'Hooghe \& Debrock 2008) as a possible developmental etiology for the endometrioid and clear cell histologies of EOC (Martin 1997, Drapkin \& Hecht 2006, Wiegand et al. 2010). Eutopic endometrium possesses the ability to activate pathways that are essential for malignant transformation. In the event of retrograde menstrual flow, those molecular alterations may facilitate endometrial tissue implantation on the surfaces of ovaries and/or peritoneum, thereby enabling tissue invasion and ultimately the manifestation of cancer (Jarboe et al. 2008, Bulun 2009). This correlates well with clinical observations and molecular studies that endometrioid and clear cell cancers develop from endometriotic implants in the ovaries and/or pelvis (Veras et al. 2009), as well as epidemiologic data that ligation, as opposed to surgical resection, of the FTs is protective primarily against these two subtypes of ovarian cancer (Rosenblatt \& Thomas 1996, Madsen et al. 2015).

\section{Mucinous cancers and transitional cell (Brenner)} cancers The origins of ovarian mucinous and transitional cell cancers are not yet fully unraveled. The majority of mucinous cancers bear no resemblance with MD-derived phenotypes but are characterized by the presence of goblet cells similar to mucosa derived from the gastrointestinal tract (Seidman \& Khedmati 2008), whereas transitional cancers have been suggested to possibly arise from metaplastic transitional epithelial nests near the tuboperitoneal junction (Kuhn et al. 2013). These nests can invaginate into the paratubal and ovarian tissue and form so-called Walthard nests, which, when embedded into the ovaries, can activate the ovarian stroma to produce androgens that facilitate the development to transitional cell tumors (Kuhn et al. 2013).

Mucinous and transitional cell cancers are strongly associated; about $25 \%$ of tumors with a mucinous component contain a Brenner component, and $\sim 16 \%$ of tumors with a Brenner component contain a mucinous

Published by Bioscientifica Ltd 
component (Seidman \& Khedmati 2008). The additional finding of amplification of chromosome 12q14-21 by comparative genome hybridization in a mucinous ovarian carcinoma and a coexisting transitional tumor gave rise to the hypothesis of a potential clonal relationship between these tumors (Pejovic et al. 1999).

Moreover recently, while not related to ovarian cancer, the epitheliotropic human papilloma virus types 16 and 18 were detected in the upper genital tract of women at high risk of developing EOC. Although it is premature to make a definitive statement based on this study, it is possible that the ascent of altered endocervical cells through the female genital tract may alter the tissue environment and facilitate development of mucinous type EOC (Bilyk et al. 2014).

\section{Ovarian cancer and stem cells}

Today, ovarian cancer is recognized as a disease with significant intra-tumor heterogeneity harboring multiple cell populations. Based on the isolation of cells with pluripotent stem cell character from murine ovaries and observations that cells with various degrees of chemosensitivity exist in ovarian cancers, it has been proposed that stem cells might be present in the premalignant epithelia that could give rise to cancers (Szotek et al. 2008, Rizzo et al. 2011, Auersperg 2013). Using protocols and markers to describe stem cells in the bone marrow (Goodell et al. 1996) or in malignancies of other organs, such as endometrial cancer or gastrointestinal tumors (Chiba et al. 2006, Friel et al. 2008, Fukuda et al. 2009), 'side population' cells, a distinct subpopulation of cells, has been identified in ovarian cancer, as well as in other types of cancers, in functional assays, which are viewed to possess stem cell characteristics (Boesch et al. 2014). These cells express the ATP-binding cassette transporter proteins G2 and B1 (Szotek et al. 2006, Hu et al. 2010, Boesch et al. 2014), drug transporter proteins that confer differential responsiveness and potential resistance to various chemotherapeutic agents. Additional proteins have been discussed as candidate ovarian cancer stem cell (CSC) markers, such as CD44 (Bapat et al. 2005), MyD88 (Alvero et al. 2009), and CD133 (Ferrandina et al. 2008); their potential role, however, remains to be elucidated.

In the breast, mammary stem cells are proposed to be recruited in a hormone-responsive process, enabling cell growth, regeneration, and functional differentiation during different phases of a woman's reproductive life (Joshi et al. 2012). In an analogous situation, epithelial stem cells in the female genital tract may also be responsive to hormonal stimuli. The niche in which they reside may serve to transmit systemic hormonal signals to the cells, as suggested for the mammary stem cell niche (Joshi et al. 2012). To date, the existence of CSCs in the human adult ovary is still a topic of debate. The existence of these cells would provide a plausible explanation for both the heterogeneity of ovarian cancer and its recurrence after effective initial treatment (Mor et al. 2011). During ovarian cancer treatment, the putative CSCs may persist quiescently in tissue niches and, due to their slow rate of cell cycling, remain unaffected by cytotoxic drugs. At later time points, they may become activated by various microenvironmental stimuli to self-renew and proliferate, causing disease recurrence (Foster et al. 2013, Shah \& Landen 2014). Gene expression profiling studies comparing normal OSE with that of ovarian serous papillary adenocarcinoma demonstrated that human OSE is certainly multipotent, albeit not omnipotent, and capable of initiating ovarian cancer (Bowen et al. 2009). The relevance of this finding, however, remains to be established, as prevailing theories do not support the idea that OSE is the precursor lesion for all EOCs but, rather, indicate that the different ovarian cancer subtypes derive from distinct cell types within the FRT. Additionally or alternatively, within the ovaries, cells lacking stem cell properties may (re-) acquire CSC properties in the presence of stress stimuli, as a consequence of cell plasticity (Tata et al. 2013). Whether these cells qualify as 'true' CSCs, however, is also controversial.

\section{Reproductive hormones and epithelial ovarian carcinogenesis}

Following menarche, the cyclic rise and fall of circulating hypothalamic-pituitary-gonadal hormonal levels govern ovarian function (Kronenberg et al. 2008). Each month, immediately prior to ovulation, gonadotropin levels surge briefly (Kronenberg et al. 2008), signaling OSE cells in the vicinity of preovulatory follicles to secrete lysosomal and proteolytic enzymes that digest the wall of the follicles, thereby facilitating oocyte release (Land 1993, Murdoch 1996). At the site of follicular rupture, the OSE becomes exposed to the stromal microenvironment (Wu et al. 1992, 1993). Fragments of the OSE become invaginated in the ovarian cortical stroma where inflammatory cells accumulate to facilitate wound repair (Radisavljevic 1977). Auto- and paracrine signals stimulate the OSE to proliferate and migrate to cover the wound area (Okamura \& Katabuchi 2001). While the OSE invaginations and formed inclusion cysts become surrounded by epithelium,

Published by Bioscientifica Ltd 
gene mutations can occur, as OSE is particularly susceptible to genetic alterations during mitosis (Godwin et al. 1992, Roby et al. 2000).

The formation of ovarian clefts and inclusion cysts increases with aging (Kronenberg et al. 2008). This coincides with the observed higher frequency of inclusion cysts in postmenopausal than in premenopausal women (66\% vs 51\%; Kronenberg et al. 2008). Genetic alterations, cellular metaplasia, and neoplastic transformation occur at the sites of repetitive tissue wounding and repair, suggesting that the microenvironment at these sites may facilitate carcinogenesis (Kronenberg et al. 2008). Repeated tissue injury in the ovary and subsequent inflammation and stromal reactions in the context of wound healing, as well as epithelial cell proliferation, may result in genetic alterations that can certainly explain, at least in part, malignant transformation. Furthermore, epithelialmesenchymal transformation (EMT) has been demonstrated in the post-ovulatory OSE (Auersperg et al. 1999, Ahmed et al. 2006). However, if the postovulatory OSE fails to undergo EMT and maintains its epithelial characteristics while being trapped within the stroma, carcinogenesis may occur (Auersperg et al. 2001). Repeated stimulation of the ectopic epithelium by stromal estrogens results in proliferation, aggregate formation and the development of inclusion cysts that are prone to metaplasia and malignant transformation. Irrespective of designation, the influence of reproductive hormones on the development and progression of ovarian cancer likely exists.

\section{Estrogens and ovarian carcinogenesis}

Numerous data implicate a role for estrogens in ovarian carcinogenesis, although the extent of its influence and the mechanistic details are unclear, given that the disease is predominantly seen in older women at or beyond the age of menopause, when estrogen levels are significantly lower than in premenopausal women. Ovarian tumor cell proliferation increases with estrogen exposure, and the estrogen receptors alpha and beta (ERA and ERB respectively) are present in $\sim 60-100 \%$ of ovarian tumors resected from patients (Lindgren et al. 2004, De Stefano et al. 2011). Stimulation of ERA increases cell proliferation, while ERB exerts the opposite effect. As ovarian cancer progresses, ERB expression is gradually lost (Lau et al. 1999, Bardin et al. 2004, Lazennec 2006), in part at a genetic level, in part due to promoter hypermethylation (Suzuki et al. 2008, Yap et al. 2009). Conversely, ERA expression remains unchanged or increases (Chan et al. 2008), resulting in a rise in the ERA/ERB ratio that evokes upregulation of tumor promoting and downregulation of tumor suppressing genes and their products (Cancer Genome Atlas Research Network 2011), thus facilitating tumor invasion and metastasis formation. In the ovary, estrogen regulates nuclear factor kappa B (NFKB) signaling, while NFKB transrepresses ERB signaling in ovarian granulosa cells (Chu et al. 2004).

Moreover, genetic susceptibility studies suggest that the polymorphism rs 1271572 within the promoter of ERB might impact the risk of ovarian cancer, particularly in women younger than 50 years (Lurie et al. 2011). Particularly, the presence of the rs1271572 TT genotype was found to confer an increased risk of malignancy (Lurie et al. 2011).

In a recent study, changes in the rate of ovarian cancer incidence were analyzed comparing the years before (1995-2002) and after (2003-2008) the 2002 Women's Health Initiative (WHI) announcement of the association of menopausal hormone therapy (MHT, also known as hormone replacement therapy) and breast cancer risk (Yang et al. 2013). A marked reduction in MHT use around 2002 led to an accelerated decline of ovarian cancer incidence rates, specifically in endometrioid histology ovarian cancers. Although this strong temporal association is not proof for a causal role of hormones in ovarian carcinogenesis, it presents an intriguing hypothesis and suggests that more research is required to answer this question (Yang et al. 2013). Similarly, the Million Women Study reported an increased risk of both incidental and fatal ovarian cancer with the use of MHT, which was more pronounced for estrogen-only agents than for combinations containing estrogen and a synthetic progesterone (Beral et al. 2007). Unfortunately, the efficacy of ER blockers (e.g., tamoxifen) or aromatase inhibitors (e.g., letrozole) has not been universally successful in treating ovarian cancer (Hatch et al. 1991, Zheng et al. 2007, Ito et al. 2011), although the response rates to tamoxifen in platinum-refractory ovarian cancer have been higher than some cytotoxic agents (Markman et al. 1996). Therefore, although it is possible that estrogens are involved in the early steps of malignant transformation, some of the tumors do not appear to depend on estrogens for sustained growth.

\section{Gonadotropins and ovarian carcinogenesis}

The prolonged use of oral contraceptives agents, irrespective of whether or not they inhibit ovulation, was shown in several epidemiologic studies to reduce the risk of

Published by Bioscientifica Ltd. 
ovarian cancer (Rosenberg et al. 1994, Lurie et al. 2007, Cibula et al. 2010, Grimbizis \& Tarlatzis 2010, Ness et al. 2011). The decreased release of endogenous estrogen during oral contraceptive use may be a consequence of reduced circulating gonadotropins levels, achieved via negative feedback regulation (Syed et al. 2001, Zheng et al. 2007).

The role of gonadotropins in ovarian carcinogenesis is particularly important given the hypergonadotropic hormonal conditions found in postmenopausal women, the most commonly affected category of patients. With the natural decline of a woman's ovarian reserve during aging, circulating gonadal steroid levels decrease while circulating pituitary gonadotropin levels rise. The constellation of low gonadal steroids, mainly estrogen, and high gonadotropin levels is characteristic for the early years after menopause (Chakravarti et al. 1976), consistent with the time period during which the incidence of ovarian cancer peaks. As menopause advances, gonadotropin levels decline slightly, although they remain elevated compared to the premenopausal state.

OSE expresses receptors for the pituitary gonadotropins, luteinizing hormone (LH) and follicle-stimulating hormone (FSH), in both the normal and cancerous states (Zheng et al. 1996, Mandai et al. 1997, Minegishi et al. 2000, Parrott et al. 2001). Expression of these receptors is higher in the early stages of epithelial ovarian carcinogenesis than in more advanced stages (Lu et al. 2000, Zheng et al. 2000), suggesting that LH and FSH are involved in activating oncogenic pathways in metaplastic OSE. This hypothesis would explain the increased rate of EOC in the peri- and postmenopausal period. The LH has also been implicated in epithelial ovarian carcinogenesis by inducing vascular endothelial growth factor (VEGF) via the phosphatidylinositide-3-kinase (PI3K)/AKT/mammalian target of rapamycin (mTOR) pathway (Liao et al. 2012) and upregulating survivin, resulting in apoptosis inhibition (Zhang et al. 2011). Similarly, VEGF is a target of FSH through the PI3K/AKT pathway (Wang et al. 2002, Sasson et al. 2003). Given the promoter effects of LH and FSH on VEGF, gonadotropin-induced VEGF expression may significantly contribute to ovarian tumor neovascularization and progression.

Human chorionic gonadotropin (hCG) comprises a group of three different molecules: regular hCG, hyperglycosylated hCG, and free $\beta$-hCG. Free $\beta$-hCG is found in many gynecologic malignancies and promotes cellular proliferation and invasion in non-gestational malignancies (Muller \& Cole 2009). While free $\beta$-hCG has been evaluated in uterine, cervical, vaginal, and ovarian malignancies, the highest sensitivity for serum $\beta$-hCG was observed in ovarian tumors, likely due to more advanced stage malignancies commonly seen with ovarian compared to other gynecologic malignancies (Muller $\&$ Cole 2009). Elevated serum $\beta$-hCG and aberrant p53 tissue expression were correlated with advanced stage, grade, age, large residual tumor size, and poor prognosis (Vartiainen et al. 2008). Although the combination of serum $\beta$-hCG and p53 may provide helpful prognostic information, few assays are currently able to detect normal and moderately elevated concentrations of serum $\beta$-hCG, or the available assays detect regular hCG and $\beta-h C G$ together, which can obscure the results (Vartiainen et al. 2008). Thus, the clinical utility of using $\beta-h C G$ as a biomarker is limited by the specificity and sensitivity of commercially available assays.

Although the link between elevated gonadotropins and ovarian cancer risk seems plausible, studies conducted in infertility patients contrast this theory. Although gonadotropin levels rise during hormonal infertility treatment, there has been no definitive link to an increased risk of ovarian cancer with their medical administration (Rizzuto et al. 2013). There may be a higher risk of borderline ovarian tumors in subfertile women treated with in vitro fertilization (Rizzuto et al. 2013), but the preponderance of data offers no convincing evidence for an elevated risk of invasive ovarian tumors associated with ovulation induction agents, including human menopausal gonadotropin, hCG, gonadotropin agonists or antagonists, and others. Nonetheless, more research in this field is required for a definitive answer.

Antiapoptotic function of gonadotropins In addition to their roles in activating oncogenic pathways, gonadotropins possess the ability to inhibit cellular apoptosis (Fig. 1). LH prevents Fas-induced apoptosis in OSE cell lines (Slot et al. 2006), while FSH does so through effects on antiapoptotic proteins, such as Bcl2, during folliculogenesis (Tilly et al. 1995). hCG binds the same receptor as LH (McFarland et al. 1989) and is frequently elevated in gynecologic malignancies (Tanyi \& Scholler 2012). hCG inhibits apoptosis of OSE cells via upregulation of insulin-like growth factor 1 and has been shown to suppress cisplatin-induced apoptosis (Kuroda et al. 2001). Similarly, FSH may also protect ovarian cancer cells against cisplatin-induced apoptosis by modulating caspase activity (Huang et al. 2003a,b).

NFKB was found to mediate antiapoptotic responses in both ovarian cancer cell lines and cultured primary ovarian cancer cells treated with the LH releasing

Published by Bioscientifica Ltd 


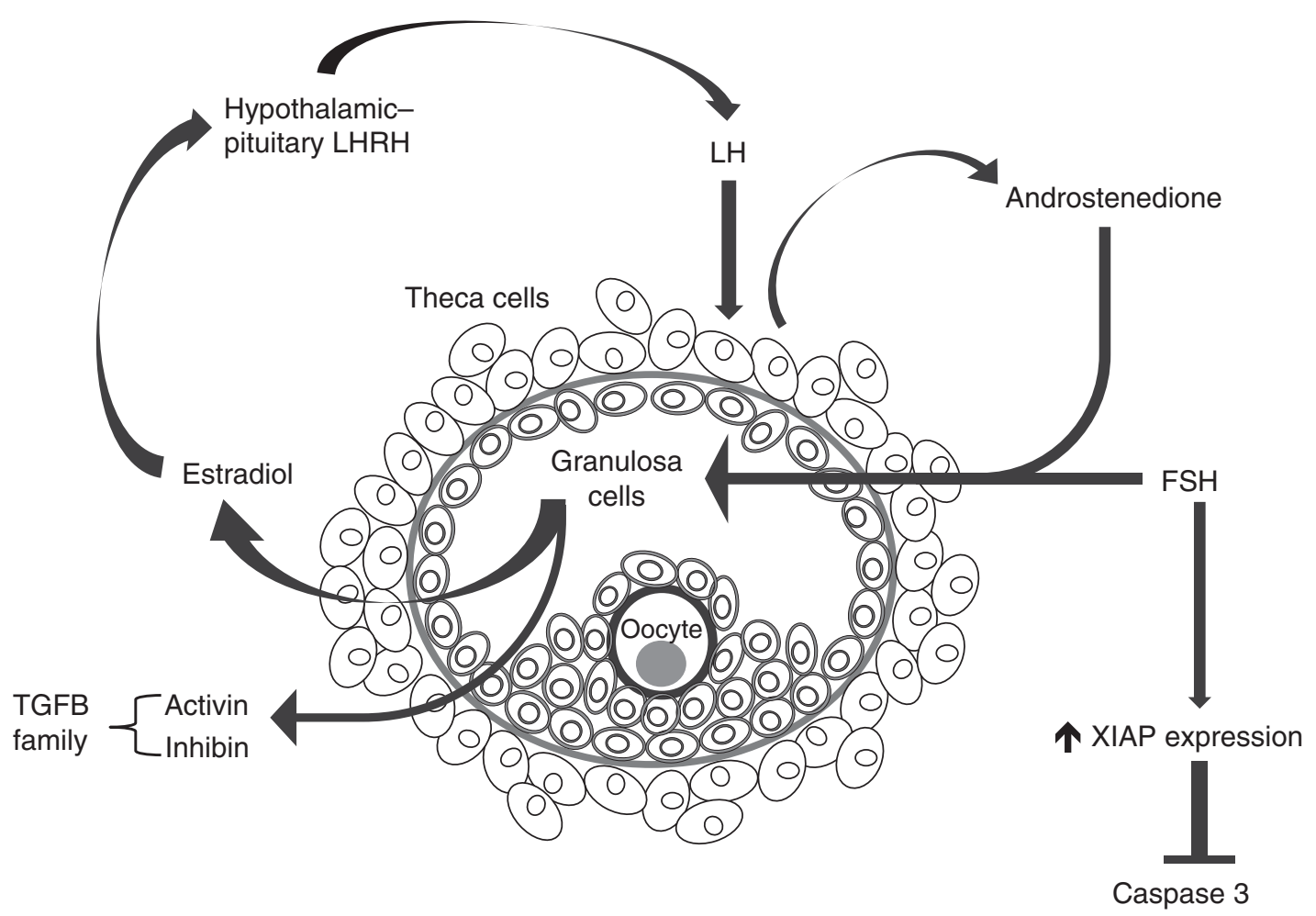

\section{Figure 1}

Hormonal interactions at the level of the oocyte. During the early phase of the menstrual cycle, FSH levels are elevated and bind FSH receptors located on granulosa cells. Theca cells express $\mathrm{LH}$ receptors. $\mathrm{LH}$ binding to theca cells promotes androstenedione production. Androstendione is subsequently, upon entering granulosa cells and under the influence of $\mathrm{FSH}$, converted to estradiol. Activins and inhibins are members of the TGFB

hormone (LHRH) analogue triptorelin that were less sensitive to doxorubicin-induced apoptosis compared to untreated cells (Gründker et al. 2000). LHRH and its receptor are expressed both within and on the surface of EOC cells. However, in contrast to the pituitary gland, where LHRH receptor signal transduction is mediated by protein kinase C (Stojilkovic \& Catt 1995), the LHRH antiproliferative effect in ovarian tumor cells results from impeding mitogenic signal transduction of growth factor receptors and oncoproteins with tyrosine kinase activity, such as epidermal growth factor (Emons et al. 1996).

In EOC, apoptosis is influenced by the inhibitors of apoptosis (IAP) proteins. For example, X-linked IAP (XIAP), a crucial inhibitor of apoptotic signaling, directly inhibits caspase 3 , a proapoptotic protease that is activated by both the intrinsic mitochondrial and the extrinsic death ligand-mediated apoptosis pathways, thereby suppressing Fas ligand and tumor necrosis factor alpha (TNFA)-induced apoptosis (Takahashi et al. 1998). Additionally, XIAP modulates the cytochrome $c /$ caspase superfamily and function antagonistically to positively and negatively regulate FSH activity, respectively. FSH promotes XIAP expression thereby promoting follicular development. XIAP inhibits pro-apoptotic caspase 3 activity. LH, luteinizing hormone; LHRH, LH releasing hormone; FSH, follicle-stimulating hormone; TGFB, transforming growth factor beta; XIAP, X-linked inhibitor of apoptosis.

9 dependent mitochondrial death pathway (McNeish et al. 2003). In cultured ovarian rat granulosa cells, FSH modulated the expression of XIAP, via NFKB activity, thus promoting follicle growth and inducing antral formation (Wang et al. 2003). On the contrary, FSH withdrawal or decreased levels of XIAP in granulosa cells led to follicular atresia.

\section{Regulation of gonadotropin levels through inhi-} bins and activins Inhibins and activins are members of the transforming growth factor beta (TGFB) family of cytokines, which influences cellular/tissue growth and differentiation and plays a role in regulating the immune system. In the ovary, inhibins and activins are produced by granulosa cells, and their primary role is to act as direct negative and positive regulators, respectively, of pituitary FSH expression and secretion (McLachlan et al. 1987, Burger 1993, Coss et al. 2010).

Activins are also expressed outside of the ovaries, such as in adrenal glands, spleen, and bone marrow (Luisi et al.

Published by Bioscientifica Ltd 
2001), and contribute to raising FSH levels. In rodentderived ovarian granulosa cells, FSH in the presence of activin was mitogenic (Miró \& Hillier 1996), offering an additional mechanistic explanation for how gonadotropins may be involved in the development of ovarian cancer during early menopause. Conversely, serum inhibin levels become undetectable after menopause when a woman's ovarian reserve has diminished. It is not yet understood how inhibins contribute to human ovarian carcinogenesis. In inhibin A-deficient mice, the observation of gonadal tumors seems to support a tumor suppressive role for inhibin (Matzuk et al. 1992), but in humans, the serum inhibin levels are elevated rather than decreased in certain types of ovarian cancer (Healy et al. 1993). Several hypotheses are proposed to explain this paradox, including the possible unresponsiveness of human ovarian cancer cells to inhibin (Matzuk et al. 1996), loss of heterozygosity involving the chromosomal region that encodes inhibin A (Watson et al. 1997), or constitutive activation of a pathway normally opposed by inhibin (Robertson et al. 2004). A clear understanding is further complicated by the fact that neither a receptor nor a binding protein for inhibin has yet been identified. Betaglycan, the TGFB type 3 receptor (TGFBR3), and InhBP/p120, a membrane-tethered proteoglycan, were identified as putative inhibin receptors, but TGFBR3 does not appear to be expressed in pituitary gonadotropes, and InhBP/p120 does not bind inhibins in conventional receptor binding assays (Bernard et al. 2002). In addition, neither appears to generate inhibin-specific intracellular signals, although both proteins appear capable of promoting inhibin-mediated antagonism of activin signaling (Bernard et al. 2002).

Despite the questionable role of inhibins in promoting ovarian carcinogenesis, it is interesting that combined inhibin and CA-125 assays detect $95 \%$ of all ovarian cancer types (Robertson et al. 1999, 2002). To date, this combination represents the most reliable clinical biomarker available for ovarian cancer diagnostics.

Gonadotropin influence on ovarian stroma Apart from the OSE, gonadotropins impact the mesenchymalderived cells of the ovarian stroma. The significance of the ovarian stroma in the pathogenesis of ovarian cancer has become increasingly clear in recent years through its numerous interactions with the OSE. Moreover, a high proportion of stroma in the cancerous ovary is associated with a decreased overall survival (OS) of patients (Labiche et al. 2010). This may be the result of insufficient drug penetration or drug resistance mechanisms dependent on cell adhesion (Anttila et al. 2000, Labiche et al. 2010).

Among the tumor-associated stromal cells that contribute to the pathogenesis of ovarian cancer are cancer-associated fibroblasts (CAFs), omentum-derived adipocytes, mesenchymal stem cells (MSCs), angiogenic precursor cells, and various types of immune cells that are actively recruited to the site of disease (Musrap \& Diamandis 2012). In addition, the ovarian stroma harbors two types of steroidogenic cells, granulosa and theca cells, which support oocytes within growing follicles. Evidence suggests that granulosa cells derive in part from OSE (Sawyer et al. 2002). They express the receptor for FSH, while the receptor for LH is expressed on the surface of theca cells in early stage follicles and on granulosa cells in later follicular maturation (Webb \& Campbell 2007). Theca cells are thought to be mesenchymal derived (Young \& McNeilly 2010). Premenopausally, the pulsatile release of LH induces them to produce androstendione, a precursor androgenic steroid hormone, which subsequently enters granulosa cells where it is converted to estradiol under the influence of FSH (aromatization; Liu \& Hsueh 1986, Simpson 2002, Kronenberg et al. 2008). Monthly gonadotropin surges cause periods of elevated estrogen levels in the ovarian stroma that could promote epithelial cell proliferation and mutagenesis, thereby creating changes favorable for carcinogenesis in the periand postmenopausal period. Indeed, gene expression profiling of ovarian cancer cells exposed to estrogen demonstrated upregulation and expression of cancerrelated and proangiogenic genes (Simpson 2002). Subpopulations of multipotent cells with the capacity to self-renew were identified among both granulosa (Kossowska-Tomaszczuk et al. 2009) and theca cells in mice (Honda et al. 2007), but not in humans. This observation has led to the hypothesis that follicular fluid may contain MSCs, which could be isolated, expanded, and potentially used for therapeutic purposes (Heng et al. 2005). One of the shortcomings of the gonadotropin hypothesis is that it does not account for the failure of MHT to protect against ovarian cancer, even though MHT lowers circulating gonadotropin levels.

\section{Androgens and ovarian carcinogenesis}

Human OSE is responsive to androgens (Edmondson et al. 2002), which are present at high levels in developing follicles (McNatty et al. 1979) as well as in the peripheral circulation. Androgens increase cellular proliferation and decrease cell death, thus, potentially influencing ovarian

Published by Bioscientifica Ltd. 
neoplastic transformation. Moreover, human ovarian cancer cells not only express $17 \beta$-hydroxysteroid dehydrogenase, the enzyme that converts the weaker androgen androstendione to the more potent testosterone (Blomquist et al. 2002), but also overexpress the androgen receptor (Ilekis et al. 1997, Lau et al. 1999). Within the androgen receptor gene, a trinucleotide (CAG) repeat polymorphism was inconsistently associated with an increased risk of developing EOC (Menin et al. 2001, Santarosa et al. 2002, Schildkraut et al. 2007, Ludwig et al. 2009).

Higher serum androstenedione and DHEA levels, as well as the use of exogenous androgens, has been associated in some studies with an increased risk of ovarian cancer (Helzlsouer et al. 1995, Cottreau et al. 2003, Olsen et al. 2008). In contrast, oral contraceptives that do not inhibit ovulation may protect against ovarian cancer by decreasing both systemic and epithelial microenvironment androgen levels (Gaspard et al. 1983, Murphy et al. 1990, Coenen et al. 1996).

Systemic hyperandrogenism occurs in women with PCOS and obesity. Both conditions can impair reproductive capacity and are reported to amplify ovarian cancer risk (Schildkraut et al. 1996, Collaborative Group on Epidemiological Studies of Ovarian Cancer 2012). Interestingly, PCOS has been linked in some cases with risk alleles of the FSH receptor (Themmen \& Huhtaniemi 2000, Gromoll \& Simoni 2005). In particular, the FSH receptor single nucleotide polymorphisms Thr307Ala and Asn680Ser have been associated with significantly increased susceptibility to serous and mucinous subtypes of ovarian cancer (Yang et al. 2006). There are studies, however, that do not support the hypothesis that androgens impact the ovarian cancer risk significantly (Cottreau et al. 2003, Greer et al. 2005, Rinaldi et al. 2007, Olsen et al. 2008), indicating that a definitive answer to this question is still pending.

\section{Progesterone and ovarian carcinogenesis}

Progesterone, an endogenous steroid hormone produced by the ovarian corpus luteum during the luteal phase of the menstrual cycle in reproductive age women, may be the common link between the hormonal and immunologic pathways. It mediates its effects via two intracellular receptor isoforms, PRA and PRB, which have distinct and differing functions in tissues of the FRT. Progesterone can attenuate and downregulate inflammatory mediators and confer potent antiproliferative and anti-inflammatory properties in the FRT, particularly by suppressing constitutive NFKB activation. As an immune modulator, progesterone promotes a humoral response, upregulating interleukin 4 (IL4), IL5, IL6, and IL10 production and inhibiting T cell proliferation (Canellada et al. 2002, De León-Nava et al. 2009). Additionally, progesterone exerts anticarcinogenic effects by inhibiting NFKB-regulated proinflammatory chemokine expression (CXCL1 and CXCL2), resulting in the suppression of proteins involved with metastasis and tumor invasion (Hernandez et al. 2010, Kavandi et al. 2012).

Although the in vivo relationship between inflammatory mediators and progesterone (or other hormonal factors) remains to be clarified, both seem to be important constituents of the ovarian tumor microenvironment and to contribute to the complex process of carcinogenesis. This is supported by observations that a portion of patients with endometriosis, a proinflammatory state of ectopic endometrial tissue in the pelvic peritoneum or ovaries, were resistant to therapy with progesterone or progestins (contraceptive steroids), although others experienced reduced tissue inflammation and pain relief (Bulun et al. 2006, Bulun 2009). PRB is expressed in eutopic endometrium but not in ectopic endometrium (Attia et al. 2000). Conversely, PRA is present in ectopic endometrium (Attia et al. 2000), albeit at very low levels. Alterations of PRA and PRB levels, paired with deficient expression of $17 \beta-$ hydroxysteroid dehydrogenase type 2 , an estradiol metabolizing enzyme, are thought to contribute to the unresponsiveness of endometriotic tissue to progesterone (Bulun et al. 2006).

The role of progesterone as an essential hormone regulating female reproductive organs is also established through its effects within the uterus. Several uterine pathologies are attributed to aberrant PR signaling, and accordingly, therapies targeting progesterone signaling are used to treat uterine pathologies, such as endometrial hyperplasia or low-grade endometrial cancer. One of the critical functions of progesterone in the uterus is to antagonize the tropic actions of estrogen on the endometrium. PR expression status in endometrial carcinoma is considered an independent prognostic factor (Ballester et al. 2013, Zhang et al. 2013) and increased PRA expression has been demonstrated in ER positive endometrial cancer (Singh et al. 2007).

In ovarian cancer cells, induction of PRB activity suppressed tumorigenicity and induced senescence (Takahashi et al. 2009). The invasive endometrioid subtype of ovarian cancer may be associated with variations of progesterone receptors, specifically when the PROGINS allele (rs1042838) is present (McKenna et al. 1995, Rowe et al. 1995, Manolitsas et al. 1997, Lancaster

Published by Bioscientifica Ltd 
et al. 1998, Spurdle et al. 2001, Tong et al. 2001, Lancaster et al. 2003, Pearce et al. 2008). On the contrary, the $+331 G / A$ polymorphism in the progesterone receptor promoter, which alters the expression of $\mathrm{PRB}$, is associated with a reduced risk of endometrioid and clear cell ovarian cancers (Berchuck et al. 2004). This may be due to the preferred production of PRB over PRA isoforms, which affects the growth and spread of endometriosis (Berchuck et al. 2004), the presumed precursor condition for those cancers (Ness 2003).

Further support for the protective effect of progesterone against ovarian carcinogenesis is gained from clinical observations. Epidemiologic data demonstrate that women with a history of twin pregnancies, and thus exposure to higher progesterone levels, are less likely to develop ovarian cancer than women with singleton pregnancies. Moreover, the protective effect of pregnancy is more pronounced in women older than 35 years, more proximal to the high risk period for ovarian cancer development, than in younger women (Whiteman et al. 2003). Indeed, the incidence rate of ovarian cancer increases during the menopausal years, when a woman's progesterone level declines - another strong indicator for the shielding effect of progesterone against the development of ovarian cancer.

\section{Endocrine influences on the immune milieu in ovarian cancer}

The immune system in premenopausal women undergoes cyclic changes coinciding with the menstrual cycle. Estrogen and progesterone are the key regulators of the immune system in the FRT (Ghosh et al. 2014) and their receptors are expressed on most immune cells (Couse et al. 1997, Dosiou et al. 2008). In the first half of a 4-week menstrual cycle (follicular phase; estrogen-driven) up to the early postovulatory phase, the FRT appears to be dominated by proinflammatory helper $\mathrm{T}$ lymphocyte 1 (Th1) cells, which exert their effects through macrophages and cytotoxic $\mathrm{T}$ cells $\left(\mathrm{CD}^{+}\right)$(Oertelt-Prigione 2012). During this phase, regulatory $\mathrm{T}$ cells $\left(\mathrm{CD} 4{ }^{+} \mathrm{CD} 25^{+} \mathrm{FOXP}^{+}\right)$also peak in number. These cells are responsible for immune modulation and the establishment of tolerance (to self-antigens). Conversely, the second half of the cycle (luteal phase; progesteronedriven) is characterized by decreased Th1 and regulatory $\mathrm{T}$ cells and increased monocytes and Th2 cells that promote proliferation of B lymphocytes.

During menopause, systemic immune function declines, which may be directly related to declining estrogen levels (Ghosh et al. 2014). A generalized inflammatory state devoid of protective immune factors, but with elevated levels of monocytes and consequently proinflammatory cytokines such as TNFA and IL6, is established in the FRT (Gameiro et al. 2010, Ghosh et al. 2014; Fig. 2A). Additionally, the total number of lymphocytes decreases during the postmenopausal years (Giglio et al. 1994, Yang et al. 2000). It is not yet clear if this is purely related to the lack of estrogen and progesterone or if other factors of aging contribute to this decline (Miller 1996, Chakravarti \& Abraham 1999).

The immune system recognizes ovarian cancer cells through their expression of tumor-associated antigens (TAAs), such as p53, Her2/neu, NY-ESO1, MUC1, MAGEA1,3,4,10, survivin, folate receptor alpha, and others. Tumor-reactive infiltrating T lymphocytes (TILs) identify TAAs spontaneously and respond with tumor-specific cytolytic activity (Santin et al. 2000). In fact, direct killing of tumor cells by cytotoxic $\mathrm{T}$ lymphocytes $\left(\mathrm{CD}^{+}\right)$is an effective antitumor immune response that positively impacts progression-free survival (PFS) and overall patient survival (Zhang et al. 2003, Hwang et al. 2012, BachmayrHeyda et al. 2013). Conversely, the presence of a high $\mathrm{CD}^{+} / \mathrm{CD} 8^{+}$TIL ratio correlated with poorer prognosis (Sato et al. 2005).

Tumors, however, have the ability to modify the balance of TILs and their function in favor of a suppressive immune microenvironment (Di et al. 2013). IL6 may be the primary immunoregulatory cytokine in epithelial ovarian carcinogenesis (Maccio \& Madeddu 2012). Produced by monocytes/macrophages as well as malignant cells, IL6 participates in multiple tumorigenic activities and demonstrates both proinflammatory and antiinflammatory effects during EOC progression. IL6 diverts the immune response from a Th1 (cell-mediated immunity) to a Th2 (humoral) response (Fig. 2B). The shift from a Th1 to a Th2 immune response is considered one of the mechanisms by which tumors evade immune destruction. Additionally, malignant cells are able to evade immune surveillance and immunologic destruction through other mechanisms, including the expression of immunosuppressive factors, impaired antigen presentation, and downregulation of intracellular adhesion molecules. The Th2 cytokines IL6 and IL10 have been shown to inhibit an inflammatory response in the tumor microenvironment (Cândido et al. 2013). High IL6 levels in the tumor microenvironment are associated with chemotherapy resistance and impaired immune cell efficiency. These functions prevent immune cell infiltration and effective apoptotic signaling (Yigit et al. 2010).

Published by Bioscientifica Ltd 
A

\begin{tabular}{l|ll|l}
\hline & \multicolumn{2}{|l|}{ Menstural cycle phase } & Menopause \\
\cline { 1 - 3 } & Follicular phase & Luteal phase & \\
\cline { 2 - 3 } & Estrogen-driven & $\begin{array}{l}\text { Progesterone- } \\
\text { driven }\end{array}$ & $\begin{array}{l}\text { Estrogen- } \\
\text { deprivation }\end{array}$ \\
$\begin{array}{llll}\text { FRT immune } \\
\text { response }\end{array}$ & $\begin{array}{l}\text { Th1 (menstrual and } \\
\text { early follicular) }\end{array}$ & $\begin{array}{l}\text { Th2 (mid-late } \\
\text { luteal) }\end{array}$ & \\
$\begin{array}{l}\text { Dominant } \\
\text { cytokines }\end{array}$ & IL1 & $\begin{array}{l}\text { IL4 } \\
\text { TNFA }\end{array}$ & IL6 \\
\hline $\begin{array}{l}\text { Systemic } \\
\text { immune } \\
\text { response }\end{array}$ & Cellular & Humoral & $\begin{array}{l}\text { Chronic state } \\
\text { of inflammatory } \\
\text { activity }\end{array}$ \\
\hline
\end{tabular}

\section{Figure 2}

(A) Immune changes in relationship to hormonal status. (B) Interactions in the tumor microenvironment between tumor cells and various immune modulators. Cancer cells alter immune responses by promoting an immunosuppressive humoral T2 immune response. Ovarian tumors also elaborate immunosuppressive cytokines, particularly IL6, IL10, and TGFB. Antitumor cytokines, including IL2, are inhibited by IL10. Tumor-associated

Ovarian cancer cells polarize monocytes and macrophages toward an immunosuppressive M2 (aka tumor associated) phenotype within the tumor microenvironment. This also enables the malignant cells to evade immune surveillance (Hagemann et al. 2006). The tumorassociated macrophages (TAMs) express angiogenic factors, such as VEGF and matrix metalloproteinases (Torres et al. 2009), and thus play a central role in mediating tumor vascularization, a process imperative for tumor growth and propagation. Accordingly, the presence of high numbers of TAMs in the ovarian microenvironment is associated with poorer clinical prognosis (Colvin 2014). TAMs also promote tumor invasion in a TNFA- and NFKB-dependent manner (Hagemann et al. 2006). This process may be facilitated in the perimenopausal and early menopausal period as circulating and local levels of steroidogenic hormones decrease, while the cellular immune response normalizes following initiation of hormone replacement (StopińskaGłuszak et al. 2006).

The combination of a generally impaired systemic immune system with a pro-inflammatory immune microenvironment in the FRT could facilitate ovarian cancer propagation. Gene expression profiling on serous and endometrioid ovarian, peritoneum, and FT tumors identified molecular subtypes with high and low immune signatures (Tothill et al. 2008). Tumors with high immune signatures were associated with better OS

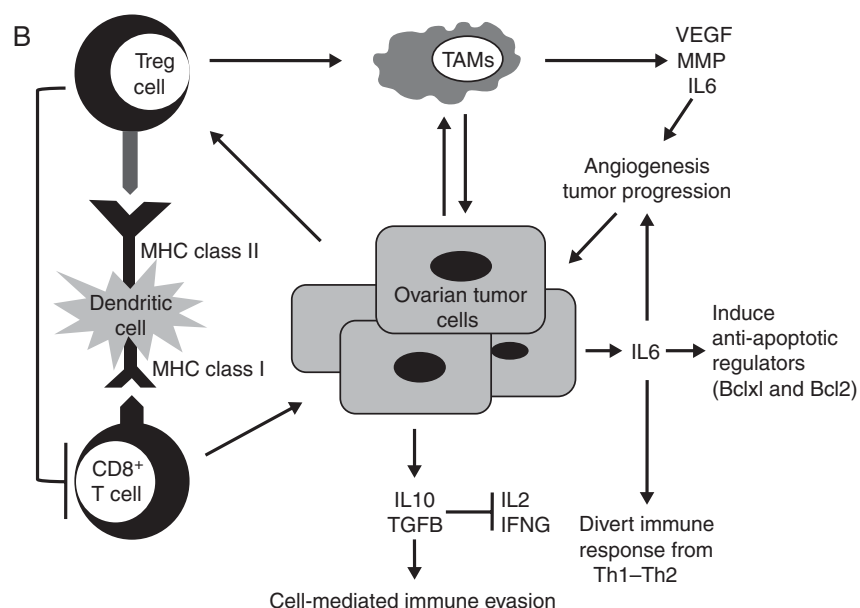

macrophages express angiogenic factors, including VEGF, further promoting tumor vascularization. Treg, regulatory T cells; VEGF, vascular endothelial growth factor; MMP, matrix metalloproteinase; IFNG, interferon gamma; TGFB, tumor growth factor beta; IL6, interleukin 6; IL10, interleukin 10; MHC, major histocompatibility complex.

(Tothill et al. 2008), suggesting that active immune signaling within the tumor confers better long-term control of ovarian cancer. Further delineation of these gene signatures is needed to identify whether they might indicate particular immune cell subsets and/or cytokines important for this survival benefit. Better characterization of hormonally induced immune changes related to these gene signatures in the postmenopausal FRT may subsequently identify potential areas for preventative intervention.

\section{Hormones and NFKB in ovarian cancer}

NFKB is a significant link between inflammation and tumor development. NFKB is a proinflammatory heterodimeric transcription factor that is found ubiquitously in many different cells of the body (Perkins 2007). It is activated by various cytokines and mitogens in response to inflammatory/immunologic changes, or other stressors, and the activation of its signaling by inflammatory mediators enhances tumorigenesis (Cohen et al. 2000). NFKB also mediates the effects of steroid hormones, including estrogen, progesterone, and androgen (Stein \& Yang 1995, Supakar et al. 1995, Kalkhoven et al. 1996, McKay \& Cidlowski 1998). The steroid/receptor complexes interact directly with NFKB inhibiting its transactivational activity (McKay \& Cidlowski 1998, 1999, Chadwick et al. 2005, Kalaitzidis \& Gilmore 2005, Kerdivel et al. 2013).

Published by Bioscientifica Ltd 
NFKB signaling is constitutively activated in some epithelial-derived tumors (Deregowski et al. 2002, Karin et al. 2002). In these tumors, NFKB mediates tissue invasion and adhesion, thereby facilitating metastasis formation, as well as promoting angiogenesis. In addition, NFKB binds to specific sites in the promoter of the phosphatidylinositol-4,5-bisphosphate 3-kinase catalytic subunit alpha (PIK3CA), an oncogenic protein present in EOC (Yang et al. 2008). PIK3CA is an important mediator of tumor cell response to stress in vivo. NFKB binds to the PIK3CA promoter after stimulation with TNFA and upregulates its gene expression (Yang et al. 2008). The PIK3CA gene itself is activated by growth factor receptor tyrosine kinases. Recently, it was hypothesized that PIK3CA is expressed at low levels in the cytoplasm of tumor cells during the initial phases of tumor growth, supporting the proliferation of tumor cells (Yang et al. 2008). However, as tumor growth progresses, nutritional support for tumor cells decreases potentiating metabolic and ischemic stress to the cells. These stresses activate NFKB to bind to the PIK3CA promoter resulting in gene expression and amplification of other downstream pathways that promote tumor cell survival and proliferation. Further exploring the NFKB pathway interactions may elucidate important biologic underpinnings to ovarian carcinogenesis.

\section{Animal models of endocrine influences on the pathogenesis of ovarian cancer}

Biskind \& Biskind (1944) developed one of the first animal models for hormone mediated ovarian cancer in 1944. In that model, ovaries were transplanted into the spleen of castrated rats, which led to the disruption of the hypothalamic-pituitary-gonadal feedback loop and loss of Graafian (antral) follicles. The loss of Graafian follicles resulted in the proliferation of the OSE, its invagination into the ovarian cortex, ovarian stromal proliferation, and in some cases, tumor formation (Biskind \& Biskind 1944, Guthrie 1957). However, if one ovary was left in situ to participate in the endocrine feedback, no proliferative changes were observed in the OSE suggesting the changes in OSE proliferation had been a consequence of hormonal alterations, specifically, the lack of negative feedback by estrogens and testosterone.

Mice thymectomized at a neonatal age experienced immune-mediated ovarian dysgenesis and developed ovarian tumors, potentially as a consequence of the continuous ovarian hyperstimulation by gonadotropins (Nishizuki et al. 1979). In a subset of transgenic mice expressing a chimeric LH $\beta$ subunit in their pituitary gonadotrophs, granulosa and stromal ovarian tumors were also observed. Again, tumor development was attributed to elevated gonadotropin (LH) levels (Risma et al. 1995). Moreover, ovarian tumors developed in mice lacking inhibin A, a hormone that suppresses FSH secretion. The resulting elevation of gonadotropin (FSH) levels in the animals was thought to underlie ovarian cancer development (Matzuk et al. 1992).

In more recent years, rodents treated with raloxifene, a selective ER modulator, demonstrated persistent elevations of serum LH levels in the absence of the preovulatory LH surge (Cohen et al. 2000, Long et al. 2001). In a study assessing the effects of raloxifene on ovarian morphology, rats were noted to develop granulosa cell hyperplasia following treatment, in a dose dependent manner, while one rat developed a granulosa cell tumor (Long et al. 2001), supporting the idea that hormonal imbalances can result in malignant transformation. Similar results were observed in ERA knockout mice in which the hypothalamic-pituitary-gonadal feedback mechanism was disturbed (Korach 1994). Once more, the increased incidence of ovarian tumors in those animals was attributed to elevated serum gonadotropin levels.

Although the number of ovarian cancer mouse models currently available remains limited, novel approaches to animal models in the last several years have brought major advances to the field. For example, patient-derived xenograft mouse models were developed that more closely mimic the true biologic progression of ovarian cancer in women and can be utilized for preclinical drug development (Kolfschoten et al. 2000). Another mouse model targeted cancer development in the FTs rather than the ovary by deleting the genes for DICER, an essential gene for microRNA synthesis, and phosphatase and tensin homolog (PTEN), a key negative regulator of the PI3K pathway. In these DICER-PTEN double-knockout mice, tumors appeared to arise from the FTs and subsequently spread to the ovary and peritoneal cavity, providing a model for FT-derived, aggressive serous carcinoma resembling human serous EOC (Kim et al. 2012). Interestingly, salpingectomy prevented the development of ovarian cancer in the double-knockout mice while oophorectomy did not, confirming FT origin. This model did not demonstrate similarities to the typical transformation that human FT secretory epithelial cells undergo during early steps of the disease pathogenesis nor did it demonstrate the formation of STICs, the pre-invasive dysplastic lesions found in association with HGSCs

Published by Bioscientifica Ltd. 
(Kindelberger et al. 2007, Lee et al. 2007). To address these points, Perets and colleagues recently developed de novo a mouse model of HGSC through Pax8-driven Cre-mediated recombinations resulting in deletions of genes that are commonly altered in the FT secretory epithelium in HGSCs (BRCA, TP53, and PTEN; Perets et al. 2013). This approach achieved both the development of precursor STIC lesions and that of advanced disease, including established HGSC and metastases, in the animals. Genomic alterations in the animals' tumors were similar to those found in corresponding patients with HGSC (TCGA 2011), thus supporting the hypothesis that HGSCs may indeed originate in the FTs and making this model a valuable tool for future research on the pathogenesis of ovarian serous carcinogenesis (Perets et al. 2013).

Apart from rodents, other animal models used to study ovarian cancer include primates, specifically macaques, and hens. In both, progestins were found to have a chemopreventive effect against ovarian (and oviductal) cancer (Rodriguez et al. 1998, 2002, Barnes et al. 2002, Trevino et al. 2012). The effect was independent of ovulation (Rodriguez et al. 2013) and likely due to the differential expression of TGFB in the ovarian epithelium, with a decreased expression of TGFB1 but an increased expression of TGFB2/3 isoforms. Because this expression pattern is associated with the induction of apoptosis in the OSE (Rodriguez et al. 2002), it could enhance the clearance of genetically damaged ovarian epithelial cells (Rodriguez et al. 2012). The discovery that the protective effect of OCPs against ovarian cancer is not due to ovulation inhibition alone has consequently sparked interest to design oral contraceptive formulations with ovarian cancer-protective potential for women.

The significance of animal models for this and other areas of ovarian cancer research has increased considerably in recent years after the discovery that the majority of established ovarian cancer cell lines do not correlate well with their reported cells of origin (Korch et al. 2012, Domcke et al. 2013). Genomic profiling, however, has been shown to be of great value in identifying cell lines that are suitable as models of ovarian cancer (Domcke et al. 2013).

\section{Therapeutic strategies for (epithelial) ovarian cancer}

The standard of care is to treat newly diagnosed ovarian cancer with cytoreductive surgery followed by platinumtaxane-based adjuvant chemotherapy. The surgery serves not only to remove the cancerous organ and its surrounding tissues but also to disrupt the hypothalamic-pituitary-gonadal endocrine axis. While up to $80 \%$ of patients initially respond to this treatment, the relapse rate is high. Relapse within 6 months of platinum-based treatment has a particularly poor outcome and resistance to platinum agents represents an obstacle for effective treatment.

\section{Endocrine treatment approaches}

Endocrine therapy may be a treatment option for women with recurrent or metastatic ovarian cancer for whom traditional chemotherapies have failed, as ovarian cancer cells tend to express receptors for reproductive hormones. It is unknown, however, which subgroup of patients is most likely to benefit from hormonal therapy.

Among the best evaluated and most frequently used hormonal agents for the treatment of ovarian cancer are the selective ER modulator tamoxifen (Schwartz et al. 1982, Hatch et al. 1991, Ahlgren et al. 1993, Johnson et al. 1993, Scambia et al. 1995, Bartlett et al. 1996, Hofstra et al. 1999, Benedetti Panici et al. 2001, Hiscox et al. 2004, Markman et al. 2004, Hasan et al. 2005, Wagner et al. 2007, Hurteau et al. 2010, Williams et al. 2010), the selective ER antagonist fulvestrant (Argenta et al. 2009), and the aromatase inhibitors letrozole (Papadimitriou et al. 2004, Smyth et al. 2007, Ramirez et al. 2008) and anastrozole (del Carmen et al. 2003, Krasner 2007). Other hormonal agents that have been evaluated in this context are progesterone receptor agonists (Ho 2003, Niwa et al. 2008, Diep et al. 2013) and antiandrogens, including flutamide and bicalutamide (Levine et al. 2007).

Hormonal inhibitors, when used in the palliative setting, serve to alleviate patients' symptoms while exposing them to less toxicity than conventional cytotoxic therapy. Hormonal agents can also play a beneficial role in modulating the tumor immune environment. Nevertheless, the response rates to these agents have been disappointing thus far, ranging between 0 and 30\% depending on the agent used, the histologic subtype of the tumor, and the patient population. The small numbers of patients included in the studies, their varying disease stages, different histologic subtypes, and treatment regimens before commencing hormonal therapy, as well as inconsistencies in determining the malignant cells' receptor status, make it difficult to form solid conclusions regarding the reasons. Clearly, randomized phase III clinical trials are indicated. Epidemiologic data suggest that the endometrioid histology ovarian cancers may be the most responsive to hormonal influences, at least in the

Published by Bioscientifica Ltd. 
initial transformation of the epithelium. The decline in incidence of this tumor subtype was the most dramatic in the period following the WHI, when MHT sharply decreased (Yang et al. 2013).

Progestins may possess a protective effect against ovarian cancer development that is attributed to the induction of OSE apoptosis (Rodriguez et al. 2002), while nonsteroidal anti-inflammatory drugs (NSAIDs) inhibit the growth and proliferation of ovarian cancer cell lines. Although the mechanisms are not yet known, it was hypothesized that these agents, given in combination, may have a beneficial synergistic effect on ovarian cancer chemoprotection and prevention (Rodriguez et al. 2012). Indeed, ovarian cancer cell lines demonstrated loss of viability and marked induction of caspase 3 by $48 \mathrm{~h}$ after treatment with progesterone and celecoxib. It remains to be determined whether the combination of these drug classes can be given over prolonged time periods to premenopausal women to protect them against the early steps of ovarian carcinogenesis. In the premenopausal period, cellular heterogeneity is thought to be negligible, and the molecular pathways mediating the effects of chemopreventives are still somewhat intact. Therefore, the combination of progestins and low-dose NSAIDS could potentially provide effective ovarian cancer chemoprotection (Rodriguez et al. 2012).

Finally, Müllerian-inhibiting substance (MIS), also known as anti-Müllerian hormone, may be cytotoxic against MD-derived tumors (Donahoe et al. 1979, 1981), as demonstrated with various ovarian cancer cell lines and in animal experiments. Presently, however, MIS is not yet applicable to be tested as an anticancer agent in a clinical setting (reviewed in Wong et al. (2014)).

\section{Treatments targeting downstream results of endocrine influences}

Given the emerging data on the efficacy of immune therapies in a subset of cancer types and an appreciation of the immunogenicity of EOC (Zhang et al. 2003), immunotherapeutic agents have been investigated in patients with ovarian cancer (Preston et al. 2011). The approaches encompass active and passive immune strategies ranging from attempts to deplete immunosuppressive regulatory $\mathrm{T}$ lymphocytes, the use of vaccines against TAAs, adoptive cell therapies, and various combinations of immune modulatory agents and modalities (Preston et al. 2011, Zsiros et al. 2014). Several groups are also exploring the effects of standard chemotherapeutic agents and radiotherapy on the ovarian cancer immune milieu. While some immune-based approaches appear promising, others have not yet led to desirable effects. The heterogeneity of ovarian cancer cells and the changes in response to hormonal influences as a tumor evolves likely allow the tumor cells to escape immune recognition and elimination, contributing to variable responses to immunotherapy. Trials are ongoing using immune modulatory agents in combination with chemotherapy, radiotherapy, and molecularly targeted agents (Zsiros et al. 2014).

Anti-angiogenic treatment with bevacizumab, a monoclonal antibody $(\mathrm{mAB})$ directed against VEGFA, has been studied in recent years for advanced, first-line therapy of ovarian cancer in combination with carboplatin and paclitaxel and for recurrent ovarian cancer following treatment with platinum-based regimens. Bevacizumab attempts to overcome the increased VEGF secretion by the CAFs and TAMs that are recruited under the influence of elevated systemic gonadotropin levels during menopause. Bevacizumab was also reported to possess immunomodulatory activity enhancing immune responses against cancer cells (Zsiros et al. 2014). In a recently reported open-label phase III trial (AURELIA), the addition of bevacizumab to chemotherapy resulted in significantly improved PFS and objective response rate (ORR) in patients with platinum-resistant ovarian cancer, although the OS was not significantly different compared to those patients who did not receive bevacizumab (PujadeLauraine et al. 2014). The reported median PFS in this trial was 6.7 months vs 3.4 months by RECIST criteria (hazard ratio (HR) $0.48, P<0.001$, on unstratified log-rank test; HR 0.42, $P<0.001$, on stratified log-rank test). The ORR was $30.9 \%$ in the bevacizumab/ chemotherapy group and $12.6 \%$ in the chemotherapy-alone group $(P<0.001)$, while the median OS was 16.6 months vs 13.3 months in those groups ( $\mathrm{HR}=0.85, P=0.174)$, respectively. Estrogen modulates angiogenesis under physiologic and pathologic conditions and has been shown to directly affect tumor growth by regulating VEGF expression (Dabrosin et al. 2003). Although there is a relationship between endocrine regulation and angiogenesis, the significance of specific hormonal interactions, particularly estrogen, with bevacizumab in the setting of ovarian cancer is unclear. Bevacizumab may oppose increased VEGF production from ovarian intratumoral estrogen derived from in situ aromatization (Sasano \& Harada 1998), effectively slowing, but not abrogating, tumor proliferation as demonstrated by ORRs without altering survival outcomes. Various clinical trials have evaluated the rational combination of aromatase inhibitors and bevacizumab in breast cancer, but none to date in ovarian cancer.

Published by Bioscientifica Ltd. 
Various signaling pathways have been implicated in gonadotropin-induced proliferation, invasion, and metastasis formation in ovarian cancer, such as the RAS/RAF/ MAPK/ERK (Pilarski et al. 2012, Stewart et al. 2012, Hilliard et al. 2013, Smolle et al. 2013), PI3K/PTEN/AKT/mTOR (Cancer Genome Atlas Research Network 2011, Huang et al. 2011, Yamamoto et al. 2011, 2012, Carden et al. 2012, Abe et al. 2013, Dobbin \& Landen 2013), and Wnt/ $\beta$-catenin signaling pathways (Bodnar et al. 2014, Ford et al. 2014, Qi et al. 2014). Gonadotropin (FSH and LH) receptors share various downstream signaling pathways, including PI3K and MAPK, and consequently, the potential crosstalk between gonadotropins and molecular pathway signaling is of great interest in exploring targeted cancer therapies. Binding either FSH or LH to their respective receptors activates ERK1/2, a subgroup of MAPKs that is involved with inhibiting apoptotis and promoting cellular proliferation and invasive potential (Mertens-Walker et al. 2012). Likewise, both FSH and LH stimulate phosphorylation of the serine/threonine kinase AKT in turn causing the activation of mTOR, a major driver of carcinogenesis (Mertens-Walker et al. 2012). Despite evidence that gonadotropin activity influences carcinogenesis, the specific mechanisms underlying the interactions between gonadotropins and carcinogenic molecular signaling remain to be better characterized.

Activation of the MAPK signaling cascade by FSH leading to phosphorylation of ERK1/2 in normal and immortalized OSE as well as EOC cell lines was first demonstrated by Choi et al. (2002). KRAS and BRAF gene mutations lead to constitutive activation of RAS/RAF/ MAPK/ERK pathway signaling (Stewart et al. 2012). Endometrioid carcinomas exhibit common molecular abnormalities with uterine endometrioid adenocarcinomas, including CTNNB1 ( $\beta$-catenin), inactivation of the PTEN on chromosome 10, microsatellite instability, and KRAS mutations (Stewart et al. 2012). The functional loss of PTEN, a mutation found in $\sim 20 \%$ of ovarian endometrioid carcinomas, impairs tumor suppressive activity (Swiersz 2002, Dobbin \& Landen 2013). KRAS, but not BRAF, mutations have been found to have an association ( $29 \%$ vs $3 \%$ respectively) with endometriosisassociated ovarian endometrioid adenocarcinomas compared to those tumors in which endometriosis was not identified (Stewart et al. 2012). This suggests that KRAS mutations and MAPK pathway activation play a role in the development of endometriosis-associated ovarian carcinomas (Stewart et al. 2012).

Deregulation of PI3K/AKT/mTOR occurs when downstream targets of PI3K are modified, or mutated.
Gonadotropins have been shown to induce gonadotropin-stimulated invasion activity of ovarian tumor cells by activating PI3K in vitro (Choi et al. 2006); FSH has been shown to increase the expression of VEGF and subsequently angiogenesis by upregulating the expression of survivin, which is activated by the PI3K pathway via AKT signaling (Huang et al. 2008, Mertens-Walker et al. 2012). Furthermore, a relationship between PI3K/AKT signaling and FSH-induced EMT in EOC cell lines has been shown (Yang et al. 2014).

Gonadotropins play a profound role in ovarian carcinogenesis including activation of multiple molecular signaling pathways directly involved with potentiating proliferation and invasion. The discovery of pathway-specific activation in different ovarian tumor histologies may guide chemotherapy selections targeted to specific pathway activity. Although specific genetic mutations are found in different ovarian tumor histologies, which has implications for therapeutic potential, targeting a single pathway may quickly lead to therapeutic resistance as other involved pathways compensate. Ultimately, the complexity of molecular signaling, redundancy, and crosstalk between signaling pathways poses significant challenges to designing effective therapies, particularly, but not exclusively, for recurrent/ refractory disease.

\section{Steps to facilitate and advance future immunotherapy of ovarian cancer}

In accordance with greater interest to advance more personalized medicine, gene expression profiling studies with linkage to clinical and pathologic features have been performed to identify novel molecular subtypes of ovarian cancer (Tothill et al. 2008). Six novel, distinct, and clinically relevant molecular subtypes were found for serous and endometrioid cancers that were driven by both the tumor and the host tissue and displayed distinct patterns of immune cell involvement (Tothill et al. 2008). Of particular interest were the findings in high-grade cancers that two of the subtypes, $\mathrm{C} 2$ and $\mathrm{C} 4$, were found to have an elevated immune signature while the $\mathrm{C} 5$ subtype was noted to have a low immune signature. Additionally, evaluation for clinical correlation among the six molecular subtypes revealed that patients with the C5 subtype trended toward early chemotherapy relapse and shorter OS (Tothill et al. 2008). Analogous subgroups were identified in the Cancer Genome Atlas, with strikingly similar relationships to survival, further supporting the influence of the immune system in ovarian cancer

Published by Bioscientifica Ltd. 
(Cancer Genome Atlas Research Network 2011). Given the interplay between hormonal factors and immune modulators in the ovarian tumor microenvironment, future research will ideally inform a greater understanding of tumor biology and pathogenesis in high-grade serous and endometrioid ovarian carcinomas and, potentially, the utility of combining hormonal or immunotherapy options for ovarian cancer treatment or prevention.

\section{Summary and conclusions}

While the specific key elements of epithelial ovarian carcinogenesis are multifactorial and the site of origin of the disease has not yet been fully elucidated, it is probable that reproductive hormones play a central role in the development of the disease. Their involvement, both systemically and locally within the ovarian microenvironment, appears to extend beyond the early stages of malignant transformation. The hormonal milieu likely modulates tumor cell evasion from immunologic surveillance/elimination, cellular proliferation, and tumor progression by the upregulation of stimulatory proteins crucial for angiogenesis (Schiffenbauer et al. 1997), neovascularization (Wang et al. 2002), tissue invasion (Choi et al. 2006), and cell adhesion (Schiffenbauer et al. 2002). These effects may be influenced by the heterogeneity underlying (epithelial) ovarian cancer and differ by tumor type and histology. Further investigation into the complex relationships and interactions between hormonal factors and the tumor immune microenvironment will help shed light on the etiology and development of (epithelial) ovarian cancer and ideally, lead to novel, effective therapeutic options.

\section{Declaration of interest}

The authors declare that there is no conflict of interest that could be perceived as prejudicing the impartiality of the review. The findings of this work do not necessarily represent the opinion of the U.S. government.

\section{Funding}

This review did not receive any specific grant from any funding agency in the public, commercial or not-for-profit sector.

\section{Acknowledgements}

We thank all colleagues whose work contributed to our knowledge in this field but could, unfortunately, not be cited due to word and space limitations. We are indebted to Dr Konrad Huppi for critically reviewing the manuscript and providing valuable comments.

\section{References}

Abe A, Minaguchi T, Ochi H, Onuki M, Okada S, Matsumoto K, Satoh T, Oki A \& Yoshikawa H 2013 PIK3CA overexpression is a possible prognostic factor for favorable survival in ovarian clear cell carcinoma. Human Pathology 44 199-207. (doi:10.1016/j.humpath.2012.05.005)

Ahlgren JD, Ellison NM, Gottlieb RJ, Laluna F, Lokich JJ, Sinclair PR, Ueno W, Wampler GL, Yeung KY, Alt D et al. 1993 Hormonal palliation of chemoresistant ovarian cancer: three consecutive phase II trials of the Mid-Atlantic Oncology Program. Journal of Clinical Oncology 11 1957-1968.

Ahmed N, Maines-Bandiera S, Quinn MA, Unger WG, Dedhar S \& Auersperg N 2006 Molecular pathways regulating EGF-induced epithelium-mesenchymal transition in human ovarian surface epithelium. American Journal of Physiology. Cell Physiology 290 C1532-C1542. (doi:10.1152/ajpcell.00478.2005)

Alvero AB, Chen R, Fu HH, Montagna M, Schwartz PE, Rutherford T, Silasi DA, Steffensen KD, Waldstrom M, Visintin I et al. 2009 Molecular phenotyping of human ovarian cancer stem cells unravels the mechanisms for repair and chemoresistance. Cell Cycle 8 158-166. (doi:10.4161/cc.8.1.7533)

Andersen MR, Goff BA, Lowe KA, Scholler N, Bergan L, Drescher CW, Paley P \& Urban N 2010 Use of a symptom index, CA125, and HE4 to predict ovarian cancer. Gynecologic Oncology 116 378-383. (doi:10.1016/j. ygyno.2009.10.087)

Anttila MA, Tammi RH, Tammi MI, Syrjänen KJ, Saarikoski SV \& Kosma VM 2000 High levels of stromal hyaluronan predict poor disease outcome in epithelial ovarian cancer. Cancer Research 60 150-155.

Argenta PA, Thomas SG, Judson PL, Downs LS Jr, Geller MA, Carson LF, Jonson AL \& Ghebre R 2009 A phase II study of fulvestrant in the treatment of multiply recurrent epithelial ovarian cancer. Gynecologic Oncology 113 205-209. (doi:10.1016/j.ygyno.2009.01.012)

Attia GR, Zeitoun K, Edwards D, Johns A, Carr BR \& Bulun SE 2000 Progesterone receptor isoform A but not B is expressed in endometriosis. Journal of Clinical Endocrinology and Metabolism 85 2897-2902.

Auersperg N 2013 The stem-cell profile of ovarian surface epithelium is reproduced in the oviductal fimbriae, with increased stem-cell marker density in distal parts of the fimbriae. International Journal of Gynecological Pathology 32 444-453. (doi:10.1097/PGP.0b013e3182800ad5)

Auersperg N, Pan J, Grove BD, Peterson T, Fisher J, Maines-Bandiera S, Somasiri A \& Roskelley CD 1999 E-cadherin induces mesenchymalto-epithelial transition in human ovarian surface epithelium. PNAS 96 6249-6254. (doi:10.1073/pnas.96.11.6249)

Auersperg N, Wong AS, Choi KC, Kang SK \& Leung PC 2001 Ovarian surface epithelium: biology, endocrinology, and pathology. Endocrine Reviews 22 255-288.

Bachmayr-Heyda A, Aust S, Heinze G, Polterauer S, Grimm C, Braicu EI, Sehouli J, Lambrechts S, Vergote I, Mahner S et al. 2013 Prognostic impact of tumor infiltrating $\mathrm{CD}^{+} \mathrm{T}$ cells in association with cell proliferation in ovarian cancer patients - a study of the OVCAD consortium. BMC Cancer 13 422. (doi:10.1186/1471-2407-13-422)

Ballester M, Canlorbe G, Cortez A, Gonin J, Laas E, Bendifallah S, Graesslin O \& Darai E 2013 Histological and immunohistochemical profiles predict lymph node status in women with low-intermediate risk endometrial cancer. Gynecologic Oncology 130 457-462. (doi:10.1016/j.ygyno.2013.06.001)

Bapat SA, Mali AM, Koppikar CB \& Kurrey NK 2005 Stem and progenitorlike cells contribute to the aggressive behavior of human epithelial ovarian cancer. Cancer Research 65 3025-3029.

Bardin A, Boulle N, Lazennec G, Vignon F \& Pujol P 2004 Loss of ER $\beta$ expression as a common step in estrogen-dependent tumor progression. Endocrine-Related Cancer 11 537-551. (doi:10.1677/erc.1. 00800)

Barnes MN, Berry WD, Straughn JM, Kirby TO, Leath CA, Huh WK, Grizzle WE \& Partridge EE 2002 A pilot study of ovarian cancer

Published by Bioscientifica Ltd 
chemoprevention using medroxyprogesterone acetate in an avian model of spontaneous ovarian carcinogenesis. Gynecologic Oncology 87 57-63. (doi:10.1006/gyno.2002.6806)

Bartlett JM, Langdon SP, Simpson BJ, Stewart M, Katsaros D, Sismondi P, Love S, Scott WN, Williams AR, Lessells AM et al. 1996 The prognostic value of epidermal growth factor receptor mRNA expression in primary ovarian cancer. British Journal of Cancer 73 301-306. (doi:10.1038/bjc. 1996.53)

Benedetti Panici P, Greggi S, Amoroso M, Scambia G, Battaglia FA, Gebbia V, Salerno G, Paratore MP \& Mancuso S 2001 A combination of platinum and tamoxifen in advanced ovarian cancer failing platinumbased chemotherapy: results of a phase II study. International Journal of Gynecological Cancer 11 438-444. (doi:10.1046/j.1525-1438.2001. 01059.x)

Beral V, Million Women Study Collaborators , Bull D, Green J \& Reeves G 2007 Ovarian cancer and hormone replacement therapy in the Million Women Study. Lancet 369 1703-1710. (doi:10.1016/S01406736(07)60534-0)

Berchuck A, Schildkraut JM, Wenham RM, Calingaert B, Ali S, Henriott A, Halabi S, Rodriguez GC, Gertig D, Purdie DM et al. 2004 Progesterone receptor promoter $+331 \mathrm{~A}$ polymorphism is associated with a reduced risk of endometrioid and clear cell ovarian cancers. Cancer Epidemiology, Biomarkers \& Prevention 13 2141-2147.

Bernard DJ, Chapman SC \& Woodruff TK 2002 Inhibin binding protein (InhBP/p120), betaglycan, and the continuing search for the inhibin receptor. Molecular Endocrinology 16 207-212. (doi:10.1210/mend.16. 2.0783)

Bilyk OO, Pande NT, Pejovic T \& Buchinska LG 2014 The frequency of human papilloma virus types 16, 18 in upper genital tract of women at high risk of developing ovarian cancer. Experimental Oncology 36 121-124.

Biskind MS \& Biskind GR 1944 Development of tumors in the rat ovary after transplantation into the spleen. Proceedings of the Society for Experimental Biology and Medicine. Society for Experimental Biology and Medicine 55 176-179. (doi:10.3181/00379727-55-14507)

Blomquist CH, Bonenfant M, McGinley DM, Posalaky Z, Lakatua DJ, Tuli-Puri S, Bealka DG \& Tremblay Y 2002 Androgenic and estrogenic $17 \beta$-hydroxysteroid dehydrogenase/17-ketosteroid reductase in human ovarian epithelial tumors: evidence for the type 1, 2 and 5 isoforms. Journal of Steroid Biochemistry and Molecular Biology 81 343-351. (doi:10. 1016/S0960-0760(02)00117-6)

Bodnar L, Stanczak A, Cierniak S, Smoter M, Cichowicz M, Kozlowski W, Szczylik C, Wieczorek M \& Lamparska-Przybysz M 2014 Wnt/ $\beta$-catenin pathway as a potential prognostic and predictive marker in patients with advanced ovarian cancer. Journal of Ovarian Research 716. (doi:10.1186/1757-2215-7-16)

Boesch M, Zeimet AG, Reimer D, Schmidt S, Gastl G, Parson W, Spoeck F, Hatina J, Wolf D \& Sopper S 2014 The side population of ovarian cancer cells defines a heterogeneous compartment exhibiting stem cell characteristics. Oncotarget 5 7027-7039. (doi:10.18632/oncotarget. 2053)

Bowen NJ, Walker LD, Matyunina LV, Logani S, Totten KA, Benigno BB \& McDonald JF 2009 Gene expression profiling supports the hypothesis that human ovarian surface epithelia are multipotent and capable of serving as ovarian cancer initiating cells. BMC Medical Genomics 271. (doi:10.1186/1755-8794-2-71)

Brinton LA, Lamb EJ, Moghissi KS, Scoccia B, Althuis MD, Mabie JE \& Westhoff CL 2004 Ovarian cancer risk associated with varying causes of infertility. Fertility and Sterility 82 405-414. (doi:10.1016/j.fertnstert. 2004.02.109)

Bulun SE 2009 Endometriosis. New England Journal of Medicine 360 268-279. (doi:10.1056/NEJMra0804690)

Bulun SE, Cheng YH, Yin P, Imir G, Utsunomiya H, Attar E, Innes J \& Julie Kim J 2006 Progesterone resistance in endometriosis: link to failure to metabolize estradiol. Molecular and Cellular Endocrinology 248 94-103. (doi:10.1016/j.mce.2005.11.041)
Burger HG 1993 Evidence for a negative feedback role of inhibin in follicle stimulating hormone regulation in women. Human Reproduction 8 (Suppl 2) 129-132. (doi:10.1093/humrep/8.suppl_2.129)

Byskov AG 1986 Differentiation of mammalian embryonic gonad. Physiological Reviews 66 71-117.

Calle EE, Rodriguez C, Walker-Thurmond K \& Thun MJ 2003 Overweight, obesity, and mortality from cancer in a prospectively studied cohort of U.S. adults. New England Journal of Medicine 348 1625-1638. (doi:10.1056/NEJMoa021423)

Cancer Genome Atlas Research Network 2011 Integrated genomic analyses of ovarian carcinoma. Nature 474 609-615. (doi:10.1038/nature10166)

Cândido EB, Silva LM, Carvalho AT, Lamaita RM, Filho RM, Cota BD \& da Silva-Filho AL 2013 Immune response evaluation through determination of type 1 , type 2 , and type 17 patterns in patients with epithelial ovarian cancer. Reproductive Sciences 20 828-837. (doi:10.1177/ 1933719112466299)

Canellada A, Blois S, Gentile T \& Margni Idehu RA 2002 In vitro modulation of protective antibody responses by estrogen, progesterone and interleukin-6. American Journal of Reproductive Immunology 48 334-343. (doi:10.1034/j.1600-0897.2002.01141.x)

Cannistra SA 2004 Cancer of the ovary. New England Journal of Medicine 351 2519-2529. (doi:10.1056/NEJMra041842)

Carden CP, Stewart A, Thavasu P, Kipps E, Pope L, Crespo M, Miranda S, Attard G, Garrett MD, Clarke PA et al. 2012 The association of PI3 kinase signaling and chemoresistance in advanced ovarian cancer. Molecular Cancer Therapeutics 11 1609-1617. (doi:10.1158/1535-7163.MCT-11-0996)

del Carmen MG, Fuller AF, Matulonis U, Horick NK, Goodman A, Duska LR, Penson R, Campos S, Roche M \& Seiden MV 2003 Phase II trial of anastrozole in women with asymptomatic Müllerian cancer. Gynecologic Oncology 91 596-602. (doi:10.1016/j.ygyno.2003.08.021)

Casagrande JT, Louie EW, Pike MC, Roy S, Ross RK \& Henderson BE 1979 "Incessant ovulation" and ovarian cancer. Lancet 2 170-173. (doi:10.1016/S0140-6736(79)91435-1)

Chadwick CC, Chippari S, Matelan E, Borges-Marcucci L, Eckert AM, Keith JC Jr, Albert LM, Leathurby Y, Harris HA, Bhat RA et al. 2005 Identification of pathway-selective estrogen receptor ligands that

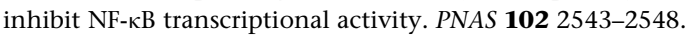
(doi:10.1073/pnas.0405841102)

Chakravarti B \& Abraham GN 1999 Aging and T-cell-mediated immunity. Mechanisms of Ageing and Development 108 183-206. (doi:10.1016/ S0047-6374(99)00009-3)

Chakravarti S, Collins WP, Forecast JD, Newton JR, Oram DH \& Studd JW 1976 Hormonal profiles after the menopause. BMJ 2 784-787. (doi:10.1136/bmj.2.6039.784)

Chan KK, Wei N, Liu SS, Xiao-Yun L, Cheung AN \& Ngan HY 2008 Estrogen receptor subtypes in ovarian cancer: a clinical correlation. Obstetrics and Gynecology 111 144-151. (doi:10.1097/01.AOG.0000296715.07705.e9)

Chen VW, Ruiz B, Killeen JL, Coté TR, Wu XC \& Correa CN 2003 Pathology and classification of ovarian tumors. Cancer 97 (10 Suppl) 2631-2642. (doi:10.1002/cncr.11345)

Chiba T, Kita K, Zheng YW, Yokosuka O, Saisho H, Iwama A, Nakauchi H \& Taniguchi H 2006 Side population purified from hepatocellular carcinoma cells harbors cancer stem cell-like properties. Hepatology $\mathbf{4 4}$ 240-251. (doi:10.1002/hep.21227)

Chittenden BG, Fullerton G, Maheshwari A \& Bhattacharya S 2009 Polycystic ovary syndrome and the risk of gynaecological cancer: a systematic review. Reproductive Biomedicine Online 19 398-405. (doi:10.1016/S1472-6483(10)60175-7)

Choi KC, Kang SK, Tai CJ, Auersperg N \& Leung PC 2002 Folliclestimulating hormone activates mitogen-activated protein kinase in preneoplastic and neoplstic ovarian surface epithelial cells. Journal of Clinical Endocrinology and Metabolism 87 2245-2253. (doi:10.1210/ jcem.87.5.8506)

Choi JH, Choi KC, Auersperg N \& Leung PC 2006 Gonadotropins activate proteolysis and increase invasion through protein kinase A and phosphatidylinositol 3-kinase pathways in human epithelial ovarian

Published by Bioscientifica Ltd. 
cancer cells. Cancer Research 66 3912-3920. (doi:10.1158/0008-5472. CAN-05-1785)

Chu S, Nishi Y, Yanase T, Nawata H \& Fuller PJ 2004 Transrepression of estrogen receptor $\beta$ signaling by nuclear factor-kb in ovarian granulosa cells. Molecular Endocrinology 18 1919-1928. (doi:10.1210/me.2004-0021)

Cibula D, Gompel A, Mueck AO, La Vecchia C, Hannaford PC, Skouby SO, Zikan M \& Dusek L 2010 Hormonal contraception and risk of cancer. Human Reproduction Update 16 631-650. (doi:10.1093/humupd/ dmq022)

Coenen CM, Thomas CM, Borm GF, Hollanders JM \& Rolland R 1996 Changes in androgens during treatment with four low-dose contraceptives. Contraception 53 171-176. (doi:10.1016/00107824(96)00006-6)

Cohen IR, Sims ML, Robbins MR, Laksmanan MC, Francis PC \& Long GG 2000 The reversible effects of raloxifene on luteinizing hormone levels and ovarian morphology in mice. Reproductive Toxicology 14 37-44. (doi:10.1016/S0890-6238(99)00065-9)

Collaborative Group on Epidemiological Studies of Ovarian Cancer 2012 Ovarian cancer and body size: individual participant meta-analysis including 25,157 women with ovarian cancer from 47 epidemiological studies. PLoS Medicine 9 e1001200. (doi:10.1371/journal.pmed.1001200)

Colvin EK 2014 Tumor-associated macrophages contribute to tumor progression in ovarian cancer. Frontiers in Oncology 137 1-6. (doi:10.3389/fonc.2014.00137)

Cooke SL \& Brenton JD 2011 Evolution of platinum resistance in high-grade serous ovarian cancer. Lancet. Oncology 12 1169-1174. (doi:10.1016/S1470-2045(11)70123-1)

Coss D, Mellon PL \& Thackray VG 2010 A FoxL in the Smad house: activin regulation of FSH. Trends in Endocrinology and Metabolism 21 562-568. (doi:10.1016/j.tem.2010.05.006)

Cottreau CM, Ness RB, Modugno F, Allen GO \& Goodman MT 2003 Endometriosis and its treatment with danazol or lupron in relation to ovarian cancer. Clinical Cancer Research 9 5142-5144.

Couse JF, Lindzey J, Grandien K, Gustafsson JA \& Korach KS 1997 Tissue distribution and quantitative analysis of estrogen receptor- $\alpha(\mathrm{ER} \alpha)$ and estrogen receptor- $\beta$ (ER $\beta$ ) messenger ribonucleic acid in the wild-type and ER $\alpha$-knockout mouse. Endocrinology 138 4613-4621.

Cramer DW \& Welch WR 1983 Determinants of ovarian cancer risk. II. Inferences regarding pathogenesis. Journal of the National Cancer Institute 71 717-721.

Cramer DW, Welch WR, Scully RE \& Wojciechowski CA 1982 Ovarian cancer and talc: a case-control study. Cancer $50372-376$. (doi:10.1002/ 1097-0142(19820715)50:2<372::AID-CNCR2820500235>3.0.CO;2-S)

Crum CP, Drapkin R, Kindelberger D, Medeiros F, Miron A \& Lee Y 2007 Lessons from BRCA: the tubal fimbria emerges as an origin for pelvic serous cancer. Clinical Medicine \& Research 5 35-44. (doi:10.3121/cmr. 2007.702)

Dabrosin C, Margetts PJ \& Gauldie J 2003 Estradiol increases extracellular levels of vascular endothelial growth factor in vivo in murine mammary cancer. International Journal of Cancer 107 535-540. (doi:10.1002/ijc. 11398)

Dehari R, Kurman RJ, Logani S \& Shih IeM 2007 The development of highgrade serous carcinoma from atypical proliferative (borderline) serous tumors and low-grade micropapillary serous carcinoma: a morphologic and molecular genetic analysis. American Journal of Surgical Pathology $\mathbf{3 1}$ 1007-1012. (doi:10.1097/PAS.0b013e31802cbbe9)

De León-Nava MA, Nava K, Soldevila G, López-Griego L, Chávez-Ríos JR, Vargas-Villavicencio JA \& Morales-Montor J 2009 Immune sexual dimorphism: effect of gonadal steroids on the expression of cytokines, sex steroid receptors, and lymphocyte proliferation. Journal of Steroid Biochemistry and Molecular Biology 113 57-64. (doi:10.1016/j.jsbmb. 2008.11.003)

Deregowski V, Delhalle S, Benoit V, Bours V \& Merville MP 2002 Identification of cytokine-induced nuclear factor- $\kappa \mathrm{B}$ target genes in ovarian and breast cancer cells. Biochemical Pharmacology 64 873-881. (doi:10.1016/S0006-2952(02)01151-6)
De Stefano I, Zannoni GF, Prisco MG, Fagotti A, Tortorella L, Vizzielli G, Mencaglia L, Scambia G \& Gallo D 2011 Cytoplasmic expression of estrogen receptor $\mathrm{b}(\mathrm{ERb})$ predicts poor clinical outcome in advanced serous ovarian cancer. Gynecologic Oncology 122 573-579. (doi:10.1016/ j.ygyno.2011.05.025)

D'Hooghe TM \& Debrock S 2008 Endometriosis, retrograde menstruation and peritoneal inflammation in women and in baboons. Human Reproduction Update 8 84-88. (doi:10.1093/humupd/8.1.84)

Di J, Duiveman-De Boer T, Figdor CG \& Torensma R 2013 Aiming to immune elimination of ovarian cancer stem cells. World Journal of Stem Cells 5 149-162. (doi:10.4252/wjsc.v5.i4.149)

Diep CH, Charles NJ, Gilks CB, Kalloger SE, Argenta PA \& Lange CA 2013 Progesterone receptors induce FOXO1-dependent senescence in ovarian cancer cells. Cell Cycle 12 1433-1449. (doi:10.4161/cc.24550)

Dietl J, Wischhusen J \& Häusler SF 2011 The post-reproductive fallopian tube: better removed? Human Reproduction 26 2918-2924. (doi:10.1093/humrep/der274)

Dobbin ZC \& Landen CN 2013 The importance of the PI3K/AKT/MTOR pathway in the progression of ovarian cancer. International Journal of Molecular Sciences 14 8213-8227. (doi:10.3390/ijms14048213)

Domcke S, Sinha R, Levine DA, Sander C \& Schultz N 2013 Evaluating cell lines as tumour models by comparison of genomic profiles. Nature Communications 4 2126. (doi:10.1038/ncomms3126)

Donahoe PK, Swann DA, Hayashi A \& Sullivan MD 1979 Müllerian duct regression in the embryo correlated with cytotoxic activity against human ovarian cancer. Science 205 913-915. (doi:10.1126/science. 472712)

Donahoe PK, Fuller AF Jr, Scully RE, Guy SR \& Budzik GP 1981 Müllerian inhibiting substance inhibits growth of a human ovarian cancer in nude mice. Annals of Surgery 194 472-480. (doi:10.1097/00000658198110000-00010)

Dosiou C, Hamilton AE, Pang Y, Overgaard MT, Tulac S, Dong J, Thomas P \& Giudice LC 2008 Expression of membrane progesterone receptors on human T lymphocytes and Jurkat cells and activation of G-proteins by progesterone. Journal of Endocrinology 196 67-77. (doi:10.1677/JOE-070317)

Drapkin RL \& Hecht JL 2006 Pathogenesis of ovarian cancer. In Diagnostic Gynecologic and Obstetric Pathology, pp 793-810. Eds CP Crum \& KR Lee. Philadelphia, PA: WB Saunders.

Dubeau L 2008 The cell of origin of ovarian epithelial tumours. Lancet. Oncology 9 1191-1197. (doi:10.1016/S1470-2045(08)70308-5)

Edmondson RJ, Monaghan JM \& Davies BR 2002 The human ovarian surface epithelium is an androgen responsive tissue. British Journal of Cancer 86 879-885. (doi:10.1038/sj.bjc.6600154)

Emons G, Muller V, Ortmann O, Grossmann G, Trautner U, Stuckrad B, Schulz K \& Schally A 1996 Luteinizing hormone-releasing hormone agonist triptorelin antagonizes signal transduction and mitogenic activity of epidermal growth factor in human ovarian and endometrial cancer cell lines. International Journal of Oncology 9 1129-1137.

Faber MT, Kjær SK, Dehlendorff C, Chang-Claude J, Andersen KK, Høgdall E, Webb PM, Jordan SJ, Australian Cancer Study (Ovarian Cancer), Australian Ovarian Cancer Study Group et al. 2013 Ovarian Cancer Association Consortium. Cigarette smoking and risk of ovarian cancer: a pooled analysis of 21 case-control studies. Cancer Causes \& Control 24 989-1004. (doi:10.1007/s10552-013-0174-4)

Falconer H, Yin L, Grönberg H \& Altman D 2015 Ovarian cancer risk after salpingectomy: a nationwide population-based study. Journal of the National Cancer Institute 107 dju410. (doi:10.1093/jnci/dju410)

Fathalla MF 1971 Incessant ovulation - a factor in ovarian neoplasia? Lancet 2 163. (doi:10.1016/S0140-6736(71)92335-X)

Ferrandina G, Bonanno G, Pierelli L, Perillo A, Procoli A, Mariotti A, Corallo M, Martinelli E, Rutella S, Paglia A et al. 2008 Expression of CD133-1 and CD133-2 in ovarian cancer. International Journal of Gynecological Cancer 18 506-514. (doi:10.1111/j.1525-1438.2007. 01056.x)

Published by Bioscientifica Ltd. 
Ford CE, Punnia-Moorthy G, Henry CE, Llamosas E, Nixdorf S, Olivier J, Caduff R, Ward RL \& Heinzelmann-Schwarz V 2014 The non-canonical Wnt ligand, Wnt5a, is upregulated and associated with epithelial to mesenchymal transition in epithelial ovarian cancer. Gynecologic Oncology 134 338-345. (doi:10.1016/j.ygyno.2014.06.004)

Foster R, Buckanovich RJ \& Rueda BR 2013 Ovarian cancer stem cells: working towards the root of stemness. Cancer Letters 338 147-157. (doi:10.1016/j.canlet.2012.10.023)

Friel AM, Sergent PA, Patnaude C, Szotek PP, Oliva E, Scadden DT, Seiden MV, Foster R \& Rueda BR 2008 Functional analyses of the cancer stem cell-like properties of human endometrial tumor initiating cells. Cell Cycle 7 242-249. (doi:10.4161/cc.7.2.5207)

Fukuda K, Saikawa Y, Ohashi M, Kumagai K, Kitajima M, Okano H, Matsuzaki Y \& Kitagawa Y 2009 Tumor initiating potential of side population cells in human gastric cancer. International Journal of Oncology 34 1201-1207.

Gameiro CM, Romão F \& Castelo-Branco C 2010 Menopause and aging: changes in the immune system - a review. Maturitas 67 316-320. (doi:10.1016/j.maturitas.2010.08.003)

Gaspard UJ, Romus MA, Gillain D, Duvivier J, Demey-Ponsart E \& Franchimont P 1983 Plasma hormone levels in women receiving new oral contraceptives containing ethinyl estradiol plus levonorgestrel or desogestrel. Contraception 27 577-590. (doi:10.1016/00107824(83)90023-9)

Ghosh M, Rodriguez-Garcia M \& Wira CR 2014 The immune system in menopause: pros and cons of hormone therapy. Journal of Steroid Biochemistry and Molecular Biology 142 171-175. (doi:10.1016/j.jsbmb. 2013.09.003)

Giglio T, Imro MA, Filaci G, Scudeletti M, Puppo F, De Cecco L, Indiveri F \& Costantini S 1994 Immune cell circulating subsets are affected by gonadal function. Life Sciences 54 1305-1312. (doi:10.1016/00243205(94)00508-7)

Godwin AK, Testa JR, Handel LM, Liu Z, Vanderveer LA, Tracey PA \& Hamilton TC 1992 Spontaneous transformation of rat ovarian surface epithelial cells: association with cytogenetic changes and implications of repeated ovulation in the etiology of ovarian cancer. Journal of the National Cancer Institute 84 592-601. (doi:10.1093/jnci/84.8.592)

Goff BA, Mandel LS, Drescher CW, Urban N, Gough S, Schurman KM, Patras J, Mahony BS \& Andersen MR 2007 Development of an ovarian cancer symptom index: possibilities for earlier detection. Cancer 109 221-227. (doi:10.1002/cncr.22371)

Gong TT, Wu QJ, Vogtmann E, Lin B \& Wang YL 2013 Age at menarche and risk of ovarian cancer: a meta-analysis of epidemiological studies. International Journal of Cancer 132 2894-2900. (doi:10.1002/ijc.27952)

Goodell MA, Brose K, Paradis G, Conner AS \& Mulligan RC 1996 Isolation and functional properties of murine hematopoietic stem cells that are replicating in vivo. Journal of Experimental Medicine 183 1797-1806. (doi:10.1084/jem.183.4.1797)

Greer JB, Modugno F, Allen GO \& Ness RB 2005 Androgenic progestins in oral contraceptives and the risk of epithelial ovarian cancer. Obstetrics and Gynecology 105 731-740. (doi:10.1097/01.AOG.0000154152. 12088.48)

Grimbizis GF \& Tarlatzis BC 2010 The use of hormonal contraception and its protective role against endometrial and ovarian cancer. Best Practice \& Research. Clinical Obstetrics \& Gynaecology 24 29-38. (doi:10.1016/j. bpobgyn.2009.08.010)

Gromoll J \& Simoni M 2005 Genetic complexity of FSH receptor function. Trends in Endocrinology and Metabolism 16 368-373. (doi:10.1016/j.tem. 2005.05.011)

Gründker C, Schulz K, Günthert AR \& Emons G 2000 Luteinizing hormonereleasing hormone induces nuclear factor $\kappa \mathrm{B}$-activation and inhibits apoptosis in ovarian cancer cells. Journal of Clinical Endocrinology and Metabolism 85 3815-3820.

Guthrie MJ 1957 Tumorigenesis in intrasplenic ovaries in mice. Cancer 10 190-203. (doi:10.1002/1097-0142(195701/02)10:1<190::AIDCNCR2820100128>3.0.CO;2-6)
Hagemann T, Wilson J, Burke F, Kulbe H, Li NF, Plüddemann A, Charles K, Gordon S \& Balkwill FR 2006 Ovarian cancer cells polarize macrophages toward a tumor-associated phenotype. Journal of Immunology $\mathbf{1 7 6}$ 5023-5032. (doi:10.4049/jimmunol.176.8.5023)

Hasan J, Ton N, Mullamitha S, Clamp A, McNeilly A, Marshall E \& Jayson GC 2005 Phase II trial of tamoxifen and goserelin in recurrent epithelial ovarian cancer. British Journal of Cancer 93 647-651. (doi:10.1038/sj.bjc.6602752)

Hatch KD, Beecham JB, Blessing JA \& Creasman WT 1991 Responsiveness of patients with advanced ovarian carcinoma to tamoxifen. A Gynecologic Oncology Group study of second-line therapy in 105 patients. Cancer 68 269-271. (doi:10.1002/10970142(19910715)68:2<269::AID-CNCR2820680209>3.0.CO;2-O)

Healy DL, Burger HG, Mamers P, Jobling T, Bangah M, Quinn M, Grant P, Day AJ, Rome R \& Campbell JJ 1993 Elevated serum inhibin concentrations in postmenopausal women with ovarian tumors. New England Journal of Medicine 329 1539-1542. (doi:10.1056/ NEJM199311183292104)

Helzlsouer KJ, Alberg AJ, Gordon GB, Longcope C, Bush TL, Hoffman SC \& Comstock GW 1995 Serum gonadotropins and steroid hormones and the development of ovarian cancer. Journal of the American Medical Association 274 1926-1930. (doi:10.1001/jama.1995.03530240036037)

Heng BC, Cao T, Bested SM, Tong GQ \& Ng SC 2005 "Waste" follicular aspirate from fertility treatment - a potential source of human germline stem cells? Stem Cells and Development 14 11-14. (doi:10.1089/scd.2005. 14.11)

Hernandez L, Hsu SC, Davidson B, Birrer MJ, Kohn EC \& Annunziata CM

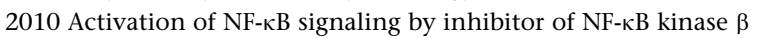
increases aggressiveness of ovarian cancer. Cancer Research 70 4005-4014. (doi:10.1158/0008-5472.CAN-09-3912)

Hilliard TS, Modi DA \& Burdette JE 2013 Gonadotropins activate oncogenic pathways to enhance proliferation in normal mouse ovarian surface epithelium. International Journal of Molecular Sciences 14 4762-4782. (doi:10.3390/ijms14034762)

Hiscox S, Morgan L, Barrow D, Dutkowskil C, Wakeling A \& Nicholson RI 2004 Tamoxifen resistance in breast cancer cells is accompanied by an enhanced motile and invasive phenotype: inhibition by gefitinib ('Iressa', ZD1839). Clinical \& Experimental Metastasis 21 201-212. (doi:10.1023/B:CLIN.0000037697.76011.1d)

Ho SM 2003 Estrogen, progesterone and epithelial ovarian cancer. Reproductive Biology and Endocrinology 1 73. (doi:10.1186/14777827-1-73)

Hofstra LS, Mourits MJ, de Vries EG, Mulder NH \& Willemse PH 1999 Combined treatment with goserelin and tamoxifen in patients with advanced chemotherapy resistant ovarian cancer. Anticancer Research $193627-3630$.

Honda A, Hirose M, Hara K, Matoba S, Inoue K, Miki H, Hiura H, KanatsuShinohara M, Kanai Y, Kono T et al. 2007 Isolation, characterization, and in vitro and in vivo differentiation of putative thecal stem cells. PNAS 104 12389-12394. (doi:10.1073/pnas.0703787104)

Hu L, McArthur C \& Jaffe RB 2010 Ovarian cancer stem-like side-population cells are tumourigenic and chemoresistant. British Journal of Cancer 102 1276-1283. (doi:10.1038/sj.bjc.6605626)

Huang CF, Liu DY \& Shen K 2003a Follicle stimulating hormone inhibits cisplatin induced apoptosis in ovarian cancer cells. Zhongguo Yi Xue Ke Xue Yuan Xue Bao. Acta Academiae Medicinae Sinicae 25 447-450.

Huang CF, Liu DY, Xu WH \& Shen K 2003b Protective effect of follicle stimulating hormone on apoptosis of human epithelial ovarian cancer cell induced by cisplatin. Zhongguo Yi Xиe Ke Xue Yuan Xue Bao. Acta Academiae Medicinae Sinicae 25 443-446.

Huang Y, Hua K, Zhou X, Jin H, Chen X, Lu X, Yu Y, Zha X \& Feng Y 2008 Activation of the PI3K/AKT pathway mediates FSH-stimulated VEGF expression in ovarian serous cystadenocarcinoma. Cell Research 18 780-791. (doi:10.1038/cr.2008.70)

Huang J, Zhang L, Greshock J, Colligon TA, Wang Y, Ward R, Katsaros D, Lassus H, Butzow R, Godwin AK et al. 2011 Frequent genetic 
abnormalities of the PI3K/AKT pathway in primary ovarian cancer predict patient outcome. Genes, Chromosomes \& Cancer 50 606-618. (doi:10.1002/gcc.20883)

Huncharek M, Geschwind JF \& Kupelnick B 2003 Perineal application of cosmetic talc and risk of invasive epithelial ovarian cancer: a meta-analysis of 11,933 subjects from sixteen observational studies. Anticancer Research 23 1955-1960.

Hurteau JA, Brady MF, Darcy KM, McGuire WP, Edmonds P, Pearl ML, Ivanov I, Tewari KS, Mannel RS, Zanotti Ket al. 2010 Randomized phase III trial of tamoxifen versus thalidomide in women with biochemicalrecurrent-only epithelial ovarian, fallopian tube or primary peritoneal carcinoma after a complete response to first-line platinum/taxane chemotherapy with an evaluation of serum vascular endothelial growth factor (VEGF): A Gynecologic Oncology Group Study. Gynecologic Oncology 119 444-450. (doi:10.1016/j.ygyno.2010.08.002)

Hwang WT, Adams SF, Tahirovic E, Hagemann IS \& Coukos G 2012 Prognostic significance of tumor-infiltrating T cells in ovarian cancer: a meta-analysis. Gynecologic Oncology 124 192-198. (doi:10.1016/j. ygyno.2011.09.039)

Ilekis JV, Connor JP, Prins GS, Ferrer K, Niederberger C \& Scoccia B 1997 Expression of epidermal growth factor and androgen receptors in ovarian cancer. Gynecologic Oncology 66 250-254. (doi:10.1006/gyno.1997.4764)

Ito K, Utsunomiya H, Niikura H, Yaegashi N \& Sasano H 2011 Inhibition of estrogen actions in human gynecological malignancies: new aspects of endocrine therapy for endometrial cancer and ovarian cancer. Molecular and Cellular Endocrinology 340 161-167. (doi:10.1016/j.mce. 2010.11.023)

Jarboe EA, Folkins AK, Drapkin R, Ince TA, Agoston ES \& Crum CP 2008 Tubal and ovarian pathways to pelvic epithelial cancer: a pathological perspective. Histopathology 53 127-138. (doi:10.1111/j.1365-2559. 2007.02938.x)

Johnson SW, Ozols RF \& Hamilton TC 1993 Mechanisms of drug resistance in ovarian cancer. Cancer 71 (2 Suppl) 644-649.

Joshi PA, Di Grappa MA \& Khokha R 2012 Active allies: hormones, stem cells and the niche in adult mammopoiesis. Trends in Endocrinology and Metabolism 23 299-309. (doi:10.1016/j.tem.2012.04.002)

Kalaitzidis D \& Gilmore TD 2005 Transcription factor cross-talk: the estrogen receptor and NF-кB. Trends in Endocrinology and Metabolism 16 46-52. (doi:10.1016/j.tem.2005.01.004)

Kalkhoven E, Wissink S, van der Saag PT \& van der Burg B 1996 Negative interaction between the RelA(p65) subunit of NF- $\kappa \mathrm{B}$ and the progesterone receptor. Journal of Biological Chemistry 271 6217-6224. (doi:10.1074/jbc.271.11.6217)

Karin M, Cao Y, Greten FR \& Li ZW 2002 NF-кB in cancer: from innocent bystander to major culprit. Nature Reviews. Cancer 2 301-310. (doi:10.1038/nrc780)

Kavandi L, Collier MA, Nguyen H \& Syed V 2012 Progesterone and calcitriol attenuate inflammatory cytokines CXCL1 and CXCL2 in ovarian and endometrial cancer cells. Journal of Cellular Biochemistry 113 3143-3152. (doi:10.1002/jcb.24191)

Kerdivel G, Boudot A \& Pakdel F 2013 Estrogen represses CXCR7 gene expression by inhibiting the recruitment of NFKB transcription factor at the CXCR7 promoter in breast cancer cells. Biochemical and Biophysical Research Communications 431 729-733. (doi:10.1016/j.bbrc.2013. 01.050)

Kim J, Coffey DM, Creighton CJ, Yu Z, Hawkins SM \& Matzuk MM 2012 High-grade serous ovarian cancer arises from fallopian tube in a mouse model. PNAS 109 3921-3926. (doi:10.1073/pnas.1117135109)

Kindelberger DW, Lee Y, Miron A, Hirsch MS, Feltmate C, Medeiros F, Callahan MJ, Garner EO, Gordon RW, Birch C et al. 2007 Intraepithelial carcinoma of the fimbria and pelvic serous carcinoma: evidence for a causal relationship. American Journal of Surgical Pathology 31 161-169. (doi:10.1097/01.pas.0000213335.40358.47)

Kolfschoten GM, Pinedo HM, Scheffer PG, Schlüper HM, Erkelens CA \& Boven E 2000 Development of a panel of 15 human ovarian cancer xenografts for drug screening anddetermination of the role of the glutathione detoxification system. Gynecologic Oncology 76 362-368. (doi:10.1006/gyno.1999.5689)

Korach KS 1994 Insights from the study of animals lacking functional estrogen receptor. Science 266 1524-1527. (doi:10.1126/science. 7985022)

Korch C, Spillman MA, Jackson TA, Jacobsen BM, Murphy SK, Lessey BA, Jordan VC \& Bradford AP 2012 DNA profiling analysis of endometrial and ovarian cell lines reveals misidentification, redundancy and contamination. Gynecologic Oncology 127 241-248. (doi:10.1016/j. ygyno.2012.06.017)

Kossowska-Tomaszczuk K, De Geyter C, De Geyter M, Martin I, Holzgreve W, Scherberich A \& Zhang H 2009 The multipotency of luteinizing granulosa cells collected from mature ovarian follicles. Stem Cells 27 210-219. (doi:10.1634/stemcells.2008-0233)

Krasner C 2007 Aromatase inhibitors in gynecologic cancers. Journal of Steroid Biochemistry and Molecular Biology 106 76-80. (doi:10.1016/j. jsbmb.2007.05.026)

Kronenberg HM, Memed S, Polonsky KS \& Larsen PR 2008 In Williams Textbook of Endocrinology. Chapter: The Physiology and Pathology of the Female Reproductive Axis, 11th edn. New York, NY, USA: Elsevier Health Sciences (ISBN: 9781416029113).

Kuhn E, Ayhan A, Shih IeM, Seidman JD \& Kurman RJ 2013 Ovarian Brenner tumour: a morphologic and immunohistochemical analysis suggesting an origin from fallopian tube epithelium. European Journal of Cancer 49 3839-3849. (doi:10.1016/j.ejca.2013.08.011)

Kuroda H, Mandai M, Konishi I, Tsuruta Y, Kusakari T, Kariya M \& Fujii S 2001 Human ovarian surface epithelial (OSE) cells express LH/hCG receptors, and hCG inhibits apoptosis of OSE cells via upregulation of insulin-like growth factor-1. International Journal of Cancer 91 309-315. (doi:10.1002/1097-0215(200002)9999:9999<::AID-IJC1060>3.0. $\mathrm{CO} ; 2-0)$

Labiche A, Heutte N, Herlin P, Chasle J, Gauduchon P \& Elie N 2010 Stromal compartment as a survival prognostic factor in advanced ovarian carcinoma. International Journal of Gynecological Cancer 20 28-33. (doi:10.1111/IGC.0b013e3181bda1cb)

Lancaster JM, Berchuck A, Carney ME, Wiseman R \& Taylor JA 1998 Progesterone receptor gene polymorphism and risk for breast and ovarian cancer. British Journal of Cancer $\mathbf{7 8} 277$. (doi:10.1038/bjc. 1998.480)

Lancaster JM, Wenham RM, Halabi S, Calingaert B, Marks JR, Moorman PG, Bentley RC, Berchuck A \& Schildkraut JM 2003 No relationship between ovarian cancer risk and progesterone receptor gene polymorphism in a population-based, case-control study in North Carolina. Cancer Epidemiology, Biomarkers \& Prevention 12 226-227.

Land JA 1993 Ovulation, ovulation induction and ovarian carcinoma. Baillière's Clinical Obstetrics and Gynaecology 7 455-472.

Lau KM, Mok SC \& Ho SM 1999 Expression of human estrogen receptor- $\alpha$ and $-\beta$, progesterone receptor, and androgen receptor mRNA in normal and malignant ovarian epithelial cells. PNAS 96 5722-5727. (doi:10.1073/pnas.96.10.5722)

Lazennec G 2006 Estrogen receptor $\beta$, a possible tumor suppressor involved in ovarian carcinogenesis. Cancer Letters 23 151-157. (doi:10.1016/j. canlet.2005.01.021)

Lee Y, Miron A, Drapkin R, Nucci MR, Medeiros F, Saleemuddin A, Garber J, Birch C, Mou H, Gordon RW et al. 2007 A candidate precursor to serous carcinoma that originates in the distal fallopian tube. Journal of Pathology 211 26-35 (Erratum in: 2007 Journal of Pathology 213 116). (doi:10.1002/path.2091)

Leeper K, Garcia R, Swisher E, Goff B, Greer B \& Paley P 2002 Pathologic findings in prophylactic oophorectomy specimens in high-risk women. Gynecologic Oncology 87 52-56. (doi:10.1006/gyno.2002.6779)

Leitzmann MF, Koebnick C, Danforth KN, Brinton LA, Moore SC, Hollenbeck AR, Schatzkin A \& Lacey JV Jr 2009 Body mass index and risk of ovarian cancer. Cancer 115 812-822. (doi:10.1002/cncr.24086)

Levine D, Park K, Juretzka M, Esch J, Hensley M, Aghajanian C, Lewin S, Konner J, Derosa F, Spriggs D et al. 2007 A phase II evaluation of 
goserelin and bicalutamide in patients with ovarian cancer in second or higher complete clinical disease remission. Cancer 110 2448-2456. (doi:10.1002/cncr.23072)

Liao H, Zhou Q, Gu Y, Duan T \& Feng Y 2012 Luteinizing hormone facilitates angiogenesis in ovarian epithelial tumor cells and metformin inhibits the effect through mTOR signaling pathway. Oncology Reports 27 1873-1878. (doi:10.3892/or.2012.1745)

Lindgren PR, Cajander S, Backstrom T, Gustafsson JA, Makela S \& Olofsson JI 2004 Estrogen and progesterone receptors in ovarian epithelial tumors. Molecular and Cellular Endocrinology 221 97-104. (doi:10.1016/j.mce.2004.02.020)

Liu YX \& Hsueh AJ 1986 Synergism between granulosa and thecainterstitial cells in estrogen biosynthesis by gonadotropin-treated rat ovaries: studies on the two-cell, two-gonadotropin hypothesis using steroid antisera. Biology of Reproduction 35 27-36. (doi:10.1095/ biolreprod35.1.27)

Long GG, Cohen IR, Gries CL, Young JK, Francis PC \& Capen CC 2001 Proliferative lesions of ovarian granulosa cell and reversible hormonal changes induced in rats by a selective estrogen-receptor modulator. Toxicologic Pathology 29 403-410. (doi:10.1080/01926230152500004)

Lu KH \& Broaddus RR 2005 Gynecologic cancers in Lynch syndrome/HNPCC. Familial Cancer 4 249-254. (doi:10.1007/s10689-0051838-3)

Lu JJ, Zheng Y, Kang X, Yuan JM, Lauchlan SC, Pike MC \& Zheng W 2000 Decreased luteinizing hormone receptor mRNA expression in human ovarian epithelial cancer. Gynecologic Oncology 79 158-168. (doi:10.1006/gyno.2000.5928)

Ludwig AH, Murawska M, Panek G, Timorek A \& Kupryjanczyk J 2009 Androgen, progesterone, and FSH receptor polymorphisms in ovarian cancer risk and outcome. Endocrine-Related Cancer 16 1005-1016. (doi:10.1677/ERC-08-0135)

Luisi S, Florio P, Reis FM \& Petraglia F 2001 Expression and secretion of activin A: possible physiological and clinical implications. European Journal of Endocrinology 145 225-236. (doi:10.1530/eje.0.1450225)

Lurie G, Thompson P, McDuffie KE, Carney ME, Terada KY \& Goodman MT 2007 Association of estrogen and progestin potency of oral contraceptives with ovarian carcinoma risk. Obstetrics and Gynecology 109 597-607. (doi:10.1097/01.AOG.0000255664.48970.e6)

Lurie G, Wilkens LR, Thompson PJ, Shvetsov YB, Matsuno RK, Carney ME, Palmieri RT, Wu AH, Pike MC, Pearce CL et al. 2011 Estrogen receptor $\beta$ rs1271572 polymorphism and invasive ovarian carcinoma risk: pooled analysis within the Ovarian Cancer Association Consortium. PLOS ONE 6 e20703. (doi:10.1371/journal.pone.0020703)

Maccio A \& Madeddu C 2012 Inflammation and ovarian cancer. Cytokine 58 133-147. (doi:10.1016/j.cyto.2012.01.015)

Madsen C, Baandrup L, Dehlendorff C \& Kjaer SK 2015 Tubal ligation and salpingectomy and the risk of epithelial ovarian cancer and borderline ovarian tumors: a nationwide case-control study. Acta Obstetricia et Gynecologica Scandinavica 94 86-94. (doi:10.1111/aogs.12516)

Mandai M, Konishi I, Kuroda H, Fukumoto M, Komatsu T, Yamamoto S, Nanbu K, Rao CV \& Mori T 1997 Messenger ribonucleic acid expression of LH/hCG receptor gene in human ovarian carcinomas. European Journal of Cancer 33 1501-1507. (doi:10.1016/S0959-8049(97)00166-4)

Manolitsas TP, Englefield P, Eccles DM \& Campbell IG 1997 No association of a 306-bp insertion polymorphism in the progesterone receptor gene with ovarian and breast cancer. British Journal of Cancer 75 1398-1399. (doi:10.1038/bjc.1997.238)

Markman M, Iseminger KA, Hatch KD, Creasman WT, Barnes W \& Dubeshter B 1996 Tamoxifen in platinum-refractory ovarian cancer: a Gynecologic Oncology Group Ancillary Report. Gynecologic Oncology 62 4-6. (doi:10.1006/gyno.1996.0181)

Markman M, Webster K, Zanotti K, Peterson G, Kulp B \& Belinson J 2004 Phase 2 trial of carboplatin plus tamoxifen in platinum-resistant ovarian cancer and primary carcinoma of the peritoneum. Gynecologic Oncology 94 404-408. (doi:10.1016/j.ygyno.2004.05.004)
Martin DC 1997 Cancer and endometriosis: do we need to be concerned? Seminars in Reproductive Endocrinology 15 319-324. (doi:10.1055/s-20081068762)

Matzuk MM, Finegold MJ, Su JG, Hsueh AJ \& Bradley A 1992 Alpha-inhibin is a tumour-suppressor gene with gonadal specificity in mice. Nature 360 313-319. (doi:10.1038/360313a0)

Matzuk MM, Kumar TR, Shou W, Coerver KA, Lau AL, Behringer RR \& Finegold MJ 1996 Transgenic models to study the roles of inhibins and activins in reproduction, oncogenesis, and development. Recent Progress in Hormone Research 51 123-154 (discussion 155-157).

McFarland KC, Sprengel R, Phillips HS, Köhler M, Rosemblit N, Nikolics K, Segaloff DL \& Seeburg PH 1989 Lutropin-choriogonadotropin receptor: an unusual member of the G protein-coupled receptor family. Science 245 494-499. (doi:10.1126/science.2502842)

McKay LI \& Cidlowski JA 1998 Cross-talk between nuclear factor-кB and the steroid hormone receptors: mechanisms of mutual antagonism. Molecular Endocrinology 12 45-56. (doi:10.1210/mend.12.1.0044)

McKay LI \& Cidlowski JA 1999 Molecular control of immune/inflammatory responses: interactions between nuclear factor- $\mathrm{\kappa} \mathrm{B}$ and steroid receptorsignaling pathways. Endocrine Reviews 20 435-459.

McKenna NJ, Kieback DG, Carney DN, Fanning M, McLinden J \& Headon DR 1995 A germline TaqI restriction fragment length polymorphism in the progesterone receptor gene in ovarian carcinoma. British Journal of Cancer 71 451-455. (doi:10.1038/bjc.1995.92)

McLachlan RI, Robertson DM, de Kretser D \& Burger HG 1987 Inhibin - a non-steroidal regulator of pituitary follicle stimulating hormone. Baillière's Clinical Endocrinology and Metabolism 1 89-112.

McNatty KP, Smith DM, Makris A, Osathanondh R \& Ryan KJ 1979 The microenvironment of the human antral follicle: interrelationships among the steroid levels in antral fluid, the population of granulosa cells, and the status of the oocyte in vivo and in vitro. Journal of Clinical Endocrinology and Metabolism 49 851-860. (doi:10.1210/jcem-49-6-851)

McNeish IA, Bell S, McKay T, Tenev T, Marani M \& Lemoine NR 2003 Expression of Smac/DIABLO in ovarian carcinoma cells induces apoptosis via a caspase-9-mediated pathway. Experimental Cell Research 286 186-198. (doi:10.1016/S0014-4827(03)00073-9)

Menin C, Banna GL, De Salvo G, Lazzarotto V, De Nicolo A, Agata S, Montagna M, Sordi G, Nicoletto O, Chieco-Bianchi L et al. 2001 Lack of association between androgen receptor CAG polymorphism and familial breast/ovarian cancer. Cancer Letters 168 31-36. (doi:10.1016/ S0304-3835(01)00473-6)

Mertens-Walker I, Baxter RC \& Marsh DJ 2012 Gonadotropin signalling in epithelial ovarian cancer. Cancer Letters 324 152-159. (doi:10.1016/j. canlet.2012.05.017)

Miller RA 1996 The aging immune system: primer and prospectus. Science 273 70-74. (doi:10.1126/science.273.5271.70)

Minegishi T, Kameda T, Hirakawa T, Abe K, Tano M \& Ibuki Y 2000 Expression of gonadotropin and activin receptor messenger ribonucleic acid in human ovarian epithelial neoplasms. Clinical Cancer Research 6 2764-2770

Miró F \& Hillier SG 1996 Modulation of granulosa cell deoxyribonucleic acid synthesis and differentiation by activin. Endocrinology 137 464-468.

Mor G, Yin G, Chefetz I, Yang Y \& Alvero A 2011 Ovarian cancer stem cells and inflammation. Cancer Biology \& Therapy 11 708-713. (doi:10.4161/ cbt.11.8.14967)

Muller CY \& Cole LA 2009 The quagmire of hCG and hCG testing in gynecologic oncology. Gynecologic Oncology 112 663-672. (doi:10. 1016/j.ygyno.2008.09.030)

Murdoch WJ 1996 Ovarian surface epithelium, ovulation and carcinogenesis. Biological Reviews of the Cambridge Philosophical Society 71 529-543. (doi:10.1111/j.1469-185X.1996.tb01283.x)

Murphy A, Cropp CS, Smith BS, Burkman RT \& Zacur HA 1990 Effect of low-dose oral contraceptive on gonadotropins, androgens, and sex hormone binding globulin in nonhirsute women. Fertility and Sterility $5335-39$.

Published by Bioscientifica Ltd. 
Musrap N \& Diamandis EP 2012 Revisiting the complexity of the ovarian cancer microenvironment - clinical implications for treatment strategies. Molecular Cancer Research 10 1254-1264. (doi:10.1158/15417786.MCR-12-0353)

Naora H 2005 Developmental patterning in the wrong context: the paradox of epithelial ovarian cancers. Cell Cycle 4 1033-1035. (doi:10.4161/cc.4.8.1906)

Ness RB 2003 Endometriosis and ovarian cancer: thoughts on shared pathophysiology. American Journal of Obstetrics and Gynecology 189 280-294. (doi:10.1067/mob.2003.408)

Ness RB \& Cottreau C 1999 Possible role of ovarian epithelial inflammation in ovarian cancer. Journal of the National Cancer Institute 91 1459-1467. (doi:10.1093/jnci/91.17.1459)

Ness RB \& Modugno F 2006 Endometriosis as a model for inflammationhormone interactions in ovarian and breast cancers. European Journal of Cancer 42 691-703. (doi:10.1016/j.ejca.2006.01.009)

Ness RB, Dodge RC, Edwards RP, Baker JA \& Moysich KB 2011 Contraception methods, beyond oral contraceptives and tubal ligation, and risk of ovarian cancer. Annals of Epidemiology 21 188-196. (doi:10.1016/ j.annepidem.2010.10.002)

Nishizuki Y, Sakahura T \& Taguchi O 1979 Mechanism of ovarian tumorigenesis in mice after neonatal thymectomy. Journal of the National Cancer Institute. Monographs 51 89-96.

Niwa K, Onogi K, Wu Y, Mori H, Harrigan RC \& Tamaya T 2008 Clinical implication of medroxyprogesterone acetate against advanced ovarian carcinoma: a pilot study. European Journal of Gynaecological Oncology 29 252-255.

Oertelt-Prigione S 2012 Immunology and the menstrual cycle. Autoimmunity Reviews 11 A486-A492. (doi:10.1016/j.autrev.2011.11.023)

Okamura H \& Katabuchi H 2001 Detailed morphology of human ovarian surface epithelium focusing on its metaplastic and neoplastic capability. Italian Journal of Anatomy and Embryology 106 (2 Suppl) 263-276.

Olsen CM, Green AC, Whiteman DC, Sadeghi S, Kolahdooz F \& Webb PM 2007 Obesity and the risk of epithelial ovarian cancer: a systematic review and meta-analysis. European Journal of Cancer 43 690-709. (doi:10.1016/j.ejca.2006.11.010)

Olsen CM, Green AC, Nagle CM, Jordan SJ, Whiteman DC, Bain CJ, Webb PM \& Australian Cancer Study Group (Ovarian Cancer) and the Australian Ovarian Cancer Study Group 2008 Epithelial ovarian cancer: testing the 'androgens hypothesis'. Endocrine-Related Cancer 15 1061-1068. (doi:10.1677/ERC-08-0075)

Papadimitriou CA, Markaki S, Siapkaras J, Vlachos G, Efstathiou E, Grimani I, Hamilos G, Zorzou M \& Dimopoulos MA 2004 Hormonal therapy with letrozole for relapsed epithelial ovarian cancer. Long-term results of a phase II study. Oncology 66 112-117. (doi:10.1159/000077436)

Parrott JA, Doraiswamy V, Kim G, Mosher R \& Skinner MK 2001 Expression and actions of both the follicle stimulating hormone receptor and the luteinizing hormone receptor in normal ovarian surface epithelium and ovarian cancer. Molecular and Cellular Endocrinology 172 213-222. (doi:10.1016/S0303-7207(00)00340-3)

Pearce CL, Wu AH, Gayther SA, Bale AE, Australian Cancer Study (Ovarian Cancer) and Australian Cancer Study Group , Beck PA, Beesley J, Chanock S, Cramer DW, DiCioccio R et al. 2008 Progesterone receptor variation and risk of ovarian cancer is limited to the invasive endometrioid subtype: results from the Ovarian Cancer Association Consortium pooled analysis. British Journal of Cancer 98 282-288. (doi:10.1038/sj.bjc.6604170)

Perets R, Wyant GA, Muto KW, Bijron JG, Poole BB, Chin KT, Chen JY, Ohman AW, Stepule CD, Kwak S et al. 2013 Transformation of the fallopian tube secretory epithelium leads to high-grade serous ovarian cancer in Brca;Tp53;Pten models. Cancer Cell 24 751-765. (doi:10.1016/j.ccr.2013.10.013)

Perkins ND 2007 Integrating cell-signaling pathways with NF-кB and IKK function. Nature Reviews. Molecular Cell Biology 8 49-62. (doi:10.1038/ nrm2083)
Pejovic T, Bürki N, Odunsi K, Fiedler P, Achong N, Schwartz PE \& Ward DC 1999 Well-differentiated mucinous carcinoma of the ovary and a coexisting Brenner tumor both exhibit amplification of 12q14-21 by comparative genomic hybridization. Gynecologic Oncology 74 134-137. (doi:10.1006/gyno.1999.5402)

Piek JM, Verheijen RH, Kenemans P, Massuger LF, Bulten H \& van Diest PJ 2003 BRCA1/2-related ovarian cancers are of tubal origin: a hypothesis. Gynecologic Oncology 90 491. (doi:10.1016/S0090-8258(03)00365-2)

Pilarski R, Patel DA, Weitzel J, McVeigh T, Dorairaj JJ, Heneghan HM, Miller N, Weidhaas JB, Kerin MJ, McKenna M et al. 2012 The KRASvariant is associated with risk of developing double primary breast and ovarian cancer. PLOS ONE 7 e37891. (doi:10.1371/journal.pone. 0037891)

Preston CC, Goode EL, Hartmann LC, Kalli KR \& Knutson KL 2011 Immunity and immune suppression in human ovarian cancer. Immunotherapy 3 539-556. (doi:10.2217/imt.11.20)

Pujade-Lauraine E, Hilpert F, Weber B, Reuss A, Poveda A, Kristensen G, Sorio R, Vergote I, Witteveen P, Bamias A et al. 2014 Bevacizumab combined with chemotherapy for platinum-resistant recurrent ovarian cancer: The AURELIA open-label randomized phase III trial. Journal of Clinical Oncology 32 1302-1308. (doi:10.1200/JCO.2013.51.4489)

Qi H, Sun B, Zhao X, Du J, Gu Q, Liu Y, Cheng R \& Dong X 2014 Wnt5a promotes vasculogenic mimicry and epithelial-mesenchymal transition via protein kinase $\mathrm{C} \alpha$ in epithelial ovarian cancer. Oncology Reports 32 771-779. (doi:10.3892/or.2014.3229)

Radisavljevic SV 1977 The pathogenesis of ovarian inclusion cysts and cystomas. Obstetrics and Gynecology 49 424-429.

Ramirez PT, Schmeler KM, Milam MR, Slomovitz BM, Smith JA, Kavanagh JJ, Deavers M, Levenback C, Coleman RL \& Gershenson DM 2008 Efficacy of letrozole in the treatment of recurrent platinum- and taxane-resistant high-grade cancer of the ovary or peritoneum. Gynecologic Oncology 110 56-59. (doi:10.1016/j.ygyno.2008.03.014)

Rinaldi S, Dossus L, Lukanova A, Peeters PH, Allen NE, Key T, Bingham S, Khaw KT, Trichopoulos D, Trichopoulou A et al. 2007 Endogenous androgens and risk of epithelial ovarian cancer: results from the European Prospective Investigation into Cancer and Nutrition (EPIC). Cancer Epidemiology, Biomarkers \& Prevention 16 23-29. (doi:10.1158/ 1055-9965.EPI-06-0755)

Risch HA 1998 Hormonal etiology of epithelial ovarian cancer, with a hypothesis concerning the role of androgens and progesterone. Journal of the National Cancer Institute 90 1774-1786. (doi:10.1093/jnci/ 90.23.1774)

Risma KA, Clay CM, Nett TM, Wagner T, Yun J \& Nilson JH 1995 Targeted overexpression of luteinizing hormone in transgenic mice leads to infertility, polycystic ovaries, and ovarian tumors. PNAS 92 1322-1326. (doi:10.1073/pnas.92.5.1322)

Rizzo S, Hersey JM, Mellor P, Dai W, Santos-Silva A, Liber D, Luk L, Titley I, Carden CP, Box G et al. 2011 Ovarian cancer stem cell-like side populations are enriched following chemotherapy and overexpress EZH2. Molecular Cancer Therapeutics 10 325-335. (doi:10.1158/15357163.MCT-10-0788)

Rizzuto I, Behrens RF \& Smith LA 2013 Risk of ovarian cancer in women treated with ovarian stimulating drugs for infertility. Cochrane Database of Systematic Reviews $\mathbf{8}$ CD008215.

Robertson DM, Cahir N, Burger HG, Mamers P, McCloud PI, Pettersson K \& McGuckin M 1999 Combined inhibin and CA125 assays in the detection of ovarian cancer. Clinical Chemistry 45 651-658.

Robertson DM, Stephenson T, Pruysers E, McCloud P, Tsigos A, Groome N, Mamers P \& Burger HG 2002 Characterization of inhibin forms and their measurement by an inhibin $\alpha$-subunit ELISA in serum from postmenopausal women with ovarian cancer. Journal of Clinical Endocrinology and Metabolism 87 816-824.

Robertson DM, Burger HG \& Fuller PJ 2004 Inhibin/activin and ovarian cancer. Endocrine-Related Cancer 11 35-49. (doi:10.1677/erc.0.0110035)

Roby KF, Taylor CC, Sweetwood JP, Cheng Y, Pace JL, Tawfik O, Persons DL, Smith PG \& Terranova PF 2000 Development of a syngeneic mouse 
model for events related to ovarian cancer. Carcinogenesis 21 585-591. (doi:10.1093/carcin/21.4.585)

Rodriguez G, Walmer DK, Cline M, Krigman H, Lessey BA, Whitaker RS, Dodge R \& Hughes CL 1998 Effect of progestin on the ovarian epithelium of macaques: cancer prevention through apoptosis? Journal of the Society for Gynecologic Investigation 5 271-276. (doi:10.1016/S1071-5576(98)00017-3)

Rodriguez GC, Nagarsheth NP, Lee KL, Bentley RC, Walmer DK, Cline M, Whitaker RS, Isner P, Berchuck A, Dodge RK et al. 2002 Progestininduced apoptosis in the Macaque ovarian epithelium: differential regulation of transforming growth factor- $\beta$. Journal of the National Cancer Institute 94 50-60. (doi:10.1093/jnci/94.1.50)

Rodriguez GC, Turbov JM, Berchuck A, Stack MS, Hurteau JA, Thaete LG \& Barry CP 2012 Nonsteroidal antiinflammatory drugs and progestins synergistically enhance cell death in ovarian epithelial cells. American Journal of Obstetrics and Gynecology 253 e1-e9. (doi:10.1016/j.ajog.2011. 11.012)

Rodriguez GC, Barnes HJ, Anderson KE, Whitaker RS, Berchuck A, Petitte JN, Lancaster JM, Wenham RM, Turbov JM, Day R et al. 2013 Evidence of a chemopreventive effect of progestin unrelated to ovulation on reproductive tract cancers in the egg-laying hen. Cancer Prevention Research 6 1283-1292. (doi:10.1158/1940-6207.CAPR-12-0426)

Rosenberg L, Palmer JR, Zauber AG, Warshauer ME, Lewis JL Jr, Strom BL, Harlap S \& Shapiro S 1994 A case-control study of oral contraceptive use and invasive epithelial ovarian cancer. American Journal of Epidemiology 139 654-661.

Rosenblatt KA \& Thomas DB 1996 Reduced risk of ovarian cancer in women with a tubal ligation or hysterectomy. The World Health Organization Collaborative Study of Neoplasia and Steroid Contraceptives. Cancer Epidemiology, Biomarkers \& Prevention 5 933-935.

Rowe SM, Coughlan SJ, McKenna NJ, Garrett E, Kieback DG, Carney DN \& Headon DR 1995 Ovarian carcinoma-associated TaqI restriction fragment length polymorphism in intron $\mathrm{G}$ of the progesterone receptor gene is due to an Alu sequence insertion. Cancer Research $\mathbf{5 5}$ 2743-2745

Salvador S, Rempel A, Soslow RA, Gilks B, Huntsman D \& Miller D 2008 Chromosomal instability in fallopian tube precursor lesions of serous carcinoma and frequent monoclonality of synchronous ovarian and fallopian tube mucosal serous carcinoma. Gynecologic Oncology 110 408-417. (doi:10.1016/j.ygyno.2008.05.010)

Sampson JA 1927 Peritoneal endometriosis due to the menstrual dissemination of endometrial tissue into the peritoneal cavity. American Journal of Obstetrics and Gynecology 14422.

Santarosa M, Bidoli E, Gallo A, Steffan A, Boiocchi M \& Viel A 2002 Polymorphic CAG repeat length within the androgen receptor gene: identification of a subgroup of patients with increased risk of ovarian cancer. Oncology Reports 9 639-644.

Santin AD, Hermonat PL, Ravaggi A, Bellone S, Pecorelli S, Cannon MJ \& Parham GP 2000 In vitro induction of tumor-specific human lymphocyte antigen class I-restricted CD8 cytotoxic T lymphocytes by ovarian antigen-pulsed autologous dendritic cells from patients with advanced ovarian cancer. American Journal of Obstetrics and Gynecology 183 601-609. (doi:10.1067/mob.2000.107097)

Sasano H \& Harada N 1998 Intratumoral aromatase in human breast, endometrial, and ovarian malignancies. Endocrine Reviews 19 593-607.

Sasson R, Dantes A, Tajima K \& Amsterdam A 2003 Novel genes modulated by FSH in normal and immortalized FSH-responsive cells: new insights into the mechanism of FSH action. FASEB Journal 17 1256-1266. (doi:10.1096/fj.02-0740com)

Sato E, Olson SH, Ahn J, Bundy B, Nishikawa H, Qian F, Jungbluth AA, Frosina D, Gnjatic S, Ambrosone C et al. 2005 Intraepithelial CD8 ${ }^{+}$ tumor-infiltrating lymphocytes and a high $\mathrm{CD}^{+} /$/regulatory $\mathrm{T}$ cell ratio are associated with favorable prognosis in ovarian cancer. PNAS 102 18538-18543. (doi:10.1073/pnas.0509182102)
Sawyer HR, Smith P, Heath DA, Juengel JL, Wakefield SJ \& McNatty KP 2002 Formation of ovarian follicle during fetal development in sheep. Biology of Reproduction 66 1134-1150. (doi:10.1095/biolreprod66.4.1134)

Scambia G, Benedetti-Panici P, Ferrandina G, Distefano M, Salerno G, Romanini ME, Fagotti A \& Mancuso S 1995 Epidermal growth factor, oestrogen and progesterone receptor expression in primary ovarian cancer: correlation with clinical outcome and response to chemotherapy. British Journal of Cancer 72 361-366. (doi:10.1038/bjc.1995.339)

Schiffenbauer YS, Abramovitch R, Meir G, Nevo N, Holzinger M, Itin A, Keshet E \& Neeman M 1997 Loss of ovarian function promotes angiogenesis in human ovarian carcinoma. PNAS 94 13203-13208. (doi:10.1073/pnas.94.24.13203)

Schiffenbauer YS, Meir G, Maoz M, Even-Ram SC, Bar-Shavit R \& Neeman M 2002 Gonadotropin stimulation of MLS human epithelial ovarian carcinoma cells augments cell adhesion mediated by CD44 and by $\alpha(v)$-integrin. Gynecologic Oncology 84 296-302. (doi:10.1006/gyno. 2001.6512)

Schildkraut JM, Schwingl PJ, Bastos E, Evanoff A \& Hughes C 1996 Epithelial ovarian cancer risk among women with polycystic ovary syndrome. Obstetrics and Gynecology 88 554-559. (doi:10.1016/00297844(96)00226-8)

Schildkraut JM, Murphy SK, Palmieri RT, Iversen E, Moorman PG, Huang Z, Halabi S, Calingaert B, Gusberg A, Marks JR et al. 2007 Trinucleotide repeat polymorphisms in the androgen receptor gene and risk of ovarian cancer. Cancer Epidemiology, Biomarkers \& Prevention 16 473-480. (doi:10.1158/1055-9965.EPI-06-0868)

Schwartz PE, Keating G, MacLusky N, Naftolin F \& Eisenfeld A 1982 Tamoxifen therapy for advanced ovarian cancer. Obstetrics and Gynecology 59 583-588.

Seidman JD \& Khedmati F 2008 Exploring the histogenesis of ovarian mucinous and transitional cell (Brenner) neoplasms and their relationship with Walthard cell nests: a study of 120 tumors. Archives of Pathology \& Laboratory Medicine 132 1753-1760. (doi:10.1043/15432165-132.11.1753)

Seidman JD, Yemelyanova A, Zaino RJ \& Kurman RJ 2011 The fallopian tube-peritoneal junction: a potential site of carcinogenesis. International Journal of Gynecological Pathology 30 4-11. (doi:10.1097/PGP. Ob013e3181f29d2a)

Shah MM \& Landen CN 2014 Ovarian cancer stem cells: are they real and why are they important? Gynecologic Oncology 132 483-489. (doi:10.1016/j.ygyno.2013.12.001)

Simpson ER 2002 Aromatization of androgens in women: current concepts and findings. Fertility and Sterility 77 (Suppl 4) 6-10. (doi:10.1016/ S0015-0282(02)02984-9)

Singh M, Zaino RJ, Filiaci VJ \& Leslie KK 2007 Relationship of estrogen and progesterone receptors to clinical outcome in metastatic endometrial carcinoma: a Gynecologic Oncology Group Study. Gynecologic Oncology 106 325-333. (doi:10.1016/j.ygyno.2007.03.042)

Slot KA, de Boer-Brouwer M, Houweling M, Vaandrager AB, Dorrington JH \& Teerds KJ 2006 Luteinizing hormone inhibits Fas-induced apoptosis in ovarian surface epithelial cell lines. Journal of Endocrinology 188 227-239. (doi:10.1677/joe.1.06087)

Smith ER \& Xu XX 2008 Ovarian ageing, follicle depletion, and cancer: a hypothesis for the aetiology of epithelial ovarian cancer involving follicle depletion. Lancet. Oncology 9 1108-1111. (doi:10.1016/S14702045(08)70281-X)

Smolle E, Taucher V, Pichler M, Petru E, Lax S \& Haybaeck J 2013 Targeting signaling pathways in epithelial ovarian cancer. International Journal of Molecular Sciences 14 9536-9555. (doi:10.3390/ijms14059536)

Smyth JF, Gourley C, Walker G, MacKean MJ, Stevenson A, Williams AR, Nafussi AA, Rye T, Rye R, Stewart M et al. 2007 Antiestrogen therapy is active in selected ovarian cancer cases: the use of letrozole in estrogen receptor positive patients. Clinical Cancer Research 13 3617-3622. (doi:10.1158/1078-0432.CCR-06-2878)

Somigliana E, Vigano P, Parazzini F, Stoppelli S, Giambattista E \& Vercellini P 2006 Association between endometriosis and cancer: a 
comprehensive review and a critical analysis of clinical and epidemiological evidence. Gynecologic Oncology 101 331-341. (doi:10.1016/j. ygyno.2005.11.033)

Spurdle AB, Webb PM, Purdie DM, Chen X, Green A \& Chenevix-Trench G 2001 No significant association between progesterone receptor exon 4 Val660Leu G/T polymorphism and risk of ovarian cancer. Carcinogenesis 22 717-721. (doi:10.1093/carcin/22.5.717)

Stein B \& Yang MX 1995 Repression of the interleukin-6 promoter by estrogen receptor is mediated by NF- $\mathrm{KB}$ and C/EBP $\beta$. Molecular and Cellular Biology 15 4971-4979.

Stewart CJ, Leung Y, Walsh MD, Walters RJ, Young JP \& Buchanan DD 2012 KRAS mutations in ovarian low-grade endometrioid adenocarcinoma: association with concurrent endometriosis. Human Pathology $\mathbf{4 3}$ 1177-1183. (doi:10.1016/j.humpath.2011.10.009)

Stojilkovic SS \& Catt KJ 1995 Expression and signal transduction pathways of gonadotropin-releasing hormone receptors. Recent Progress in Hormone Research 50 161-205.

Stopińska-Głuszak U, Waligóra J, Grzela T, Głuszak M, Jóźwiak J, Radomski D, Roszkowski PI \& Malejczyk J 2006 Effect of estrogen/ progesterone hormone replacement therapy on natural killer cell cytotoxicity and immunoregulatory cytokine release by peripheral blood mononuclear cells of postmenopausal women. Journal of Reproductive Immunology 69 65-75. (doi:10.1016/j.jri.2005.07.006)

Supakar PC, Jung MH, Song CS, Chatterjee B \& Roy AK 1995 Nuclear factor $\kappa \mathrm{B}$ functions as a negative regulator for the rat androgen receptor gene and NF- $\kappa \mathrm{B}$ activity increases during the age-dependent desensitization of the liver. Journal of Biological Chemistry 270 837-842. (doi:10.1074/ jbc.270.2.837)

Suzuki F, Akahira J, Miura I, Suzuki T, Ito K, Hayashi S, Sasano H \& Yaegashi N 2008 Loss of estrogen receptor $\beta$ isoform expression and its correlation with aberrant DNA methylation of the $5^{\prime}$-untranslated region in human epithelial ovarian carcinoma. Cancer Science $\mathbf{9 9}$ 2365-2372. (doi:10.1111/j.1349-7006.2008.00988.x)

Swiersz LM 2002 Role of endometriosis in cancer and tumor development. Annals of the New York Academy of Sciences 955 281-292. (doi:10.1111/j. 1749-6632.2002.tb02788.x)

Syed V, Ulinski G, Mok SC, Yiu GK \& Ho SM 2001 Expression of gonadotropin receptor and growth responses to key reproductive hormones in normal and malignant human ovarian surface epithelial cells. Cancer Research 61 6768-6776.

Szotek PP, Pieretti-Vanmarcke R, Masiakos PT, Dinulescu DM, Connolly D, Foster R, Dombkowski D, Preffer F, Maclaughlin DT \& Donahoe PK 2006 Ovarian cancer side population defines cells with stem cell-like characteristics and Müllerian inhibiting substance responsiveness. PNAS 103 11154-11159. (doi:10.1073/pnas.0603672103)

Szotek PP, Chang HL, Brennand K, Fujino A, Pieretti-Vanmarcke R, Lo Celso C, Dombkowski D, Preffer F, Cohen KS, Teixeira J et al. 2008 Normal ovarian surface epithelial label-retaining cells exhibit stem/ progenitor cell characteristics. PNAS 105 12469-12473 (Erratum in: 2008 PNAS 105 19024). (doi:10.1073/pnas.0805012105)

Takahashi R, Deveraux Q, Tamm I, Welsh K, Assa-Munt N, Salvesen GS \& Reed JC 1998 A single BIR domain of XIAP sufficient for inhibiting caspases. Journal of Biological Chemistry 273 7787-7790. (doi:10.1074/ jbc.273.14.7787)

Takahashi A, Kato K, Kuboyama A, Inoue T, Tanaka Y, Kuhara A, Kinoshita K, Takeda S \& Wake N 2009 Induction of senescence by progesterone receptor-B activation in response to cAMP in ovarian cancer cells. Gynecologic Oncology 113 270-276. (doi:10.1016/j.ygyno. 2008.12.032)

Tanyi JL \& Scholler N 2012 Oncology biomarkers for gynecologic malignancies. Frontiers in Bioscience: A Journal and Virtual Library $\mathbf{4}$ 1097-1110. (doi:10.2741/E444)

Tata PR, Mou H, Pardo-Saganta A, Zhao R, Prabhu M, Law BM, Vinarsky V, Cho JL, Breton S, Sahay A et al. 2013 Dedifferentiation of committed epithelial cells into stem cells in vivo. Nature 503 218-223. (doi:10.1038/nature12777)
Themmen APN \& Huhtaniemi IT 2000 Mutations of gonadotropins and gonadotropin receptors: elucidating the physiology and pathophysiology of pituitary-gonadal function. Endocrine Reviews 21 551-583. (doi:10.1210/edrv.21.5.0409)

Tilly JL, Tilly KI, Kenton ML \& Johnson AL 1995 Expression of members of the bcl-2 gene family in the immature rat ovary: equine chorionic gonadotropin-mediated inhibition of granulosa cell apoptosis is associated with decreased bax and constitutive bcl-2 and bcl-x long messenger ribonucleic acid levels. Endocrinology 136 232-241.

Tone AA, Salvador S, Finlayson SJ, Tinker AV, Kwon JS, Lee CH, Cohen T, Ehlen T, Lee M, Carey MS et al. 2012 The role of the fallopian tube in ovarian cancer. Clinical Advances in Hematology \& Oncology 10 296-306.

Tong D, Fabjani G, Heinze G, Obermair A, Leodolter S \& Zeillinger R 2001 Analysis of the human progesterone receptor gene polymorphism progins in Austrian ovarian carcinoma patients. International Journal of Cancer 95 394-397. (doi:10.1002/1097-0215(20011120)95:6< 394::AID-IJC1070 > 3.0.CO;2-X)

Torres MP, Ponnusamy MP, Lakshmanan I \& Batra SK 2009 Immunopathogenesis of ovarian cancer. Minerva Medica 100 385-400.

Tothill RW, Tinker AV, George J, Brown R, Fox SB, Lade S, Johnson DS, Trivett MK, Etemadmoghadam D, Locandro B et al. 2008 Novel molecular subtypes of serous and endometrioid ovarian cancer linked to clinical outcome. Clinical Cancer Research 14 5198-5208. (doi:10.1158/1078-0432.CCR-08-0196)

Trevino LS, Buckles EL \& Johnson PA 2012 Oral contraceptives decrease the prevalence of ovarian cancer in the hen. Cancer Prevention Research 5 343-349. (doi:10.1158/1940-6207.CAPR-11-0344)

Tung KH, Goodman MT, Wu AH, McDuffie K, Wilkens LR, Kolonel LN, Nomura AM, Terada KY, Carney ME \& Sobin LH 2003 Reproductive factors and epithelial ovarian cancer risk by histologic type: a multiethnic case-control study. American Journal of Epidemiology 158 629-638. (doi:10.1093/aje/kwg177)

Vartiainen J, Lassus H, Lehtovirta P, Finne P, Alfthan H, Butzow R \& Stenman UH 2008 Combination of serum hCG $\beta$ and p53 tissue expression defines distinct subgroups of serous ovarian carcinoma. International Journal of Cancer 122 2125-2129. (doi:10.1002/ijc.23322)

Veras E, Mao TL, Ayhan A, Ueda S, Lai H, Hayran M, Shih IeM \& Kurman RJ 2009 Cystic and adenofibromatous clear cell carcinomas of the ovary: distinctive tumors that differ in their pathogenesis and behavior: a clinicopathologic analysis of 122 cases. American Journal of Surgical Pathology 33 844-853. (doi:10.1097/PAS.0b013e31819c4271)

Wagner U, du Bois A, Pfisterer J, Huober J, Loibl S, Lück HJ, Sehouli J, Gropp M, Stähle A, Schmalfeldt B et al. 2007 Gefitinib in combination with tamoxifen in patients with ovarian cancer refractory or resistant to platinum-taxane based therapy - a phase II trial of the AGO Ovarian Cancer Study Group (AGO-OVAR 2.6). Gynecologic Oncology 105 132-137. (doi:10.1016/j.ygyno.2006.10.053)

Walker GR, Schlesselman JJ \& Ness RB 2002 Family history of cancer, oral contraceptive use, and ovarian cancer risk. American Journal of Obstetrics and Gynecology 186 8-14. (doi:10.1067/mob.2002.118657)

Wang J, Luo F, Lu JJ, Chen PK, Liu P \& Zheng W 2002 VEGF expression and enhanced production by gonadotropins in ovarian epithelial tumors. International Journal of Cancer 97 163-167. (doi:10.1002/ijc.1593)

Wang Y, Rippstein PU \& Tsang BK 2003 Role and gonadotrophic regulation of X-linked inhibitor of apoptosis protein expression during rat ovarian follicular development in vitro. Biology of Reproduction 68 610-619. (doi:10.1095/biolreprod.102.007807)

Watson RH, Roy WJ Jr, Davis M, Hitchcock A \& Campbell IG 1997 Loss of heterozygosity at the $\alpha$-inhibin locus on chromosome $2 \mathrm{q}$ is not a feature of human granulosa cell tumors. Gynecologic Oncology 65 387-390. (doi:10.1006/gyno.1997.4682)

Webb R \& Campbell BK 2007 Development of the dominant follicle: mechanisms of selection and maintenance of oocyte quality. Society of Reproduction and Fertility Supplement 64 141-163. 
Whiteman DC, Siskind V, Purdie DM \& Green AC 2003 Timing of pregnancy and the risk of epithelial ovarian cancer. Cancer Epidemiology, Biomarkers \& Prevention 12 42-46.

Wiegand KC, Shah SP, Al-Agha OM, Zhao Y, Tse K, Zeng T, Senz J, McConechy MK, Anglesio MS, Kalloger SE et al. 2010 ARID1A mutations in endometriosis-associated ovarian carcinomas. New England Journal of Medicine 363 1532-1543. (doi:10.1056/ NEJMoa1008433)

Williams C, Simera I \& Bryant A 2010 Tamoxifen for relapse of ovarian cancer. Cochrane Database of Systematic Reviews 3 CD001034. (doi:10.1002/14651858.CD001034)

Wong RR, Worley MJ Jr, Chung TK \& Wong YF 2014 An update on Müllerian-inhibiting substance: its potential application against ovarian cancer. Endocrine-Related Cancer 21 R227-R233. (doi:10.1530/ ERC-14-0030)

Wu S, Rodabaugh K, Martinez-Maza O, Watson JM, Silberstein DS, Boyer CM, Peters WP, Weinberg JB, Berek JS \& Bast RC Jr 1992 Stimulation of ovarian tumor cell proliferation with monocyte products including interleukin-1, interleukin-6, and tumor necrosis factor- $\alpha$. American Journal of Obstetrics and Gynecology 166 997-1007. (doi:10.1016/0002-9378(92)91379-O)

Wu S, Boyer CM, Whitaker RS, Berchuck A, Wiener JR, Weinberg JB \& Bast RC Jr 1993 Tumor necrosis factor $\alpha$ as an autocrine and paracrine growth factor for ovarian cancer: monokine induction of tumor cell proliferation and tumor necrosis factor $\alpha$ expression. Cancer Research $\mathbf{5 3}$ 1939-1944.

Yamamoto S, Tsuda H, Takano M, Iwaya K, Tamai S \& Matsubara O 2011 PIK3CA mutation is an early event in the development of endometriosis-associated ovarian clear cell adenocarcinoma. Journal of Pathology 225 189-194. (doi:10.1002/path.2940)

Yamamoto S, Tsuda H, Takano M, Tamai S \& Matsubara O 2012 PIK3CA mutations and loss of ARID1A protein expression are early events in the development of cystic ovarian clear cell adenocarcinoma. Virchows Archiv 460 77-87. (doi:10.1007/s00428-011-1169-8)

Yang JH, Chen CD, Wu MY, Chao KH, Yang YS \& Ho HN 2000 Hormone replacement therapy reverses the decrease in natural killer cytotoxicity but does not reverse the decreases in the T-cell subpopulation or interferon- $\gamma$ production in postmenopausal women. Fertility and Sterility 74 261-267. (doi:10.1016/S0015-0282(00)00622-1)

Yang CQ, Chan KY, Ngan HY, Khoo US, Chiu PM, Chan QK, Xue WC \& Cheung AN 2006 Single nucleotide polymorphisms of follicle-stimulating hormone receptor are associated with ovarian cancer susceptibility. Carcinogenesis 27 1502-1506. (doi:10.1093/carcin/bgl014)

Yang N, Huang J, Greshock J, Liang S, Barchetti A, Hasegawa K, Kim S, Giannakakis A, Li C, O'Brien-Jenkins A et al. 2008 Transcriptional regulation of PIK3CA oncogene by NF- $\mathrm{KB}$ in ovarian cancer microenvironment. PLoS ONE 3 e1758. (doi:10.1371/journal.pone.0001758)
Yang HP, Anderson WF, Rosenberg PS, Trabert B, Gierach GL, Wentzensen N, Cronin KA \& Sherman ME 2013 Ovarian cancer incidence trends in relation to changing patterns of menopausal hormone therapy use in the United States. Journal of Clinical Oncology 31 2146-2151. (doi:10. 1200/JCO.2012.45.5758)

Yang Y, Zhang J, Zhu Y, Zhang Z, Sun H \& Feng Y 2014 Follicle-stimulating hormone induced epithelial-mesenchymal transition of epithelial ovarian cancer cells through follicle-stimulating hormone receptor PI3K/Akt-Snail signaling pathway. International Journal of Gynecological Cancer 24 1564-1574. (doi:10.1097/IGC.0000000000000279)

Yap OW, Bhat G, Liu L \& Tollefsbol TO 2009 Epigenetic modifications of the estrogen receptor $\beta$ gene in epithelial ovarian cancer cells. Anticancer Research 29 139-144.

Yigit R, Massuger LF, Figdor CG \& Torensma R 2010 Ovarian cancer creates a suppressive microenvironment to escape immune elimination. Gynecologic Oncology 117 366-372. (doi:10.1016/j.ygyno.2010.01.019)

Young JM \& McNeilly AS 2010 Theca: the forgotten cell of the ovarian follicle. Reproduction 140 489-504. (doi:10.1530/REP-10-0094)

Zhang L, Conejo-Garcia JR, Katsaros D, Gimotty PA, Massobrio M, Regnani G, Makrigiannakis A, Gray H, Schlienger K, Liebman MN et al. 2003 Intratumoral $\mathrm{T}$ cells, recurrence, and survival in epithelial ovarian cancer. New England Journal of Medicine 348 203-213. (doi:10.1056/ NEJMoa020177)

Zhang Z, Liao H, Chen X, Zheng Y, Liu Y, Tao X, Gu C, Dong L, Duan T, Yang Y et al. 2011 Luteinizing hormone upregulates survivin and inhibits apoptosis in ovarian epithelial tumors. European Journal of Obstetrics, Gynecology, and Reproductive Biology 155 69-74. (doi:10.1016/ j.ejogrb.2010.10.017)

Zhang GY, Wu LY, Li B, Huang MN, Zhang R \& Li XG 2013 Retrospective analysis of prognostic variables and clinical outcomes in surgically staged intermediate risk endometrial carcinoma. European Journal of Obstetrics, Gynecology, and Reproductive Biology 169 309-316. (doi:10. 1016/j.ejogrb.2013.02.025)

Zheng W, Magid MS, Kramer EE \& Chen YT 1996 Follicle-stimulating hormone receptor is expressed in human ovarian surface epithelium and fallopian tube. American Journal of Pathology 148 47-53.

Zheng W, Lu JJ, Luo F, Zheng Y, Feng YJ, Felix JC, Lauchlan SC \& Pike MC 2000 Ovarian epithelial tumor growth promotion by follicle-stimulating hormone and inhibition of the effect by luteinizing hormone. Gynecologic Oncology 76 80-88. (doi:10.1006/gyno.1999.5628)

Zheng H, Kavanagh JJ, Hu W, Liao Q \& Fu S 2007 Hormonal therapy in ovarian cancer. International Journal of Gynecological Cancer 17 325-338. (doi:10.1111/j.1525-1438.2006.00749.x)

Zsiros E, Tanyi J, Balint K \& Kandalaft LE 2014 Immunotherapy for ovarian cancer: recent advances and perspectives. Current Opinion in Oncology 26 492-500. (doi:10.1097/CCO.0000000000000111)

Received in final form 13 August 2015

Accepted 15 September 2015

Made available online as an Accepted Preprint

15 September 2015 http://erc.endocrinology-journals.org DOI: 10.1530/ERC-14-0550
(C) 2015 Society for Endocrinology Printed in Great Britain
Published by Bioscientifica Ltd. 